\title{
The transcription factor TpRfx1 is an essential regulator of amylase and cellulase gene expression in Talaromyces pinophilus
}

\author{
Gui-Yan Liao ${ }^{\dagger}$, Shuai Zhao ${ }^{*}{ }^{\dagger}$ Ting Zhang, Cheng-Xi Li, Lu-Sheng Liao, Feng-Fei Zhang, Xue-Mei Luo \\ and Jia-Xun Feng ${ }^{*}$ (D)
}

\begin{abstract}
Background: Perfect and low cost of fungal amylolytic and cellulolytic enzymes are prerequisite for the industrialization of plant biomass biorefinergy to biofuels. Genetic engineering of fungal strains based on regulatory network of transcriptional factors (TFs) and their targets is an efficient strategy to achieve the above described aim. Talaromyces pinophilus produces integrative amylolytic and cellulolytic enzymes; however, the regulatory mechanism associated with the expression of amylase and cellulase genes in T. pinophilus remains unclear. In this study, we screened for and identified novel TFs regulating amylase and/or cellulase gene expression in T. pinophilus 1-95 through comparative transcriptomic and genetic analyses.
\end{abstract}

Results: Comparative analysis of the transcriptomes from T. pinophilus 1-95 grown on media in the presence and absence of glucose or soluble starch as the sole carbon source screened 33 candidate TF-encoding genes that regulate amylase gene expression. Thirty of the 33 genes were successfully knocked out in the parental strain T. pinophilus $\triangle T p K u 70$, with seven of the deletion mutants firstly displaying significant changes in amylase production as compared with the parental strain. Among these, $\triangle T p R f \times 1$ (TpRfx1: Talaromyces pinophilus Rfx 1 ) showed the most significant decrease (81.5\%) in amylase production, as well as a 57.7\% reduction in filter paper cellulase production. Real-time quantitative reverse transcription PCR showed that $T p R f x 1$ dynamically regulated the expression of major amylase and cellulase genes during cell growth, and in vitro electrophoretic mobility shift assay revealed that TpRf 1 bound the promoter regions of genes encoding a-amylase (TP04014/Amy13A), glucoamylase (TP09267/Amy15A), cellobiohydrolase (TP09412/cbh1), $\beta$-glucosidase (TP05820/bg/1), and endo- $\beta$-1,4-glucanase (TP08514/eg1). TpRfx1 protein containing a regulatory factor $X$ (RFX) DNA-binding domain belongs to RFX family.

Conclusion: We identified a novel RFX protein TpRFX1 that directly regulates the expression of amylase and cellulase genes in T. pinophilus, which provides new insights into the regulatory mechanism of fungal amylase and cellulase gene expression.

Keywords: Talaromyces pinophilus, Transcription factor, Regulation, Amylase, Cellulase

\footnotetext{
*Correspondence: shuaizhao0227@gxu.edu.cn; jiaxunfeng@sohu.com

${ }^{\dagger}$ Gui-Yan Liao and Shuai Zhao contributed equally to this work

State Key Laboratory for Conservation and Utilization of Subtropical

Agro-bioresources, Guangxi Research Center for Microbial and Enzyme

Engineering Technology, College of Life Science and Technology, Guangxi

University, 100 Daxue Road, Nanning 530004, Guangxi, People's Republic

of China
}

(c) The Author(s) 2018. This article is distributed under the terms of the Creative Commons Attribution 4.0 International License (http://creativecommons.org/licenses/by/4.0/), which permits unrestricted use, distribution, and reproduction in any medium, provided you give appropriate credit to the original author(s) and the source, provide a link to the Creative Commons license, and indicate if changes were made. The Creative Commons Public Domain Dedication waiver (http://creativecommons.org/ publicdomain/zero/1.0/) applies to the data made available in this article, unless otherwise stated. 


\section{Background}

The filamentous fungus Talaromyces pinophilus, formerly Penicillium pinophilum in the Penicillium subgenus Biverticillium, is a member of the family Trichocomaceae belonging to the order Eurotiales (class Eurotiomycetes; phylum Ascomycota) [1]. T. pinophilus produces yellow colonies, darker-green conidium, and red pigment, with changes in colony color to yellow, orange, or red-to-purplish red shades on potato dextrose agar (PDA) plates [2].

Talaromyces pinophilus has been potentially applied in the biotechnological industry due to its ability to produce integrative amylolytic and cellulolytic enzymes [3]. Amylases, including $\alpha$-amylase (EC 3.2.1.1), glucoamylase (EC 3.2.1.3), $\alpha$-glucosidase (EC 3.2.1.20), and 1,4- $\alpha$-glucanbranching enzyme (EC 2.4.1.18), degrade starches, with $\alpha$-amylase attacking the $\alpha$-1,4-glycosidic bonds of amylopectin or amylose to generate varying lengths of straight chains and branched oligosaccharides and glucoamylase breaking $\alpha$-1,4- or $\alpha$-1,6-glucosidic linkages at the nonreducing ends of starch chains or dextrin [4].

Cellulases include endo- $\beta$-1,4-glucanase (EG; EC 3.2.1.4), cellobiohydrolase (CBH; EC 3.2.1.91), and $\beta$-glucosidase (BGL; EC 3.2.1.21), with EG attacking internal $\beta$-1,4-glycosidic bonds of cellulose chains to release chain ends, $\mathrm{CBH}$ hydrolyzing cellulose chains from both ends to release cellobiose, and BGL hydrolyzing the resulting soluble cellooligosaccharides and cellobiose products into glucose [5].

Transcriptional expression of fungal amylase and cellulase genes is regulated by transcription factors (TFs), with the expression of both enzyme genes co-regulated under certain conditions. A lack of the TF AmyR induces the expression of cellulase genes and represses the transcription of amylase genes in Penicillium oxalicum [6] and Aspergillus niger [7]. Conversely, the high-mobility group box protein PoxHmbB positively regulates the expression of major cellulase genes and negatively controls the expression of amylase genes in P. oxalicum [8]. Additionally, the deletion of $\mathrm{creA} / \mathrm{creB}$ involved in carbon catabolite repression response to glucose not only improves $\alpha$-amylase production but also enhances cellulase and xylanase activities [9]. However, studies identifying TFs responsible for co-regulating the expression of amylase and cellulase genes are limited and insufficient to describe the regulatory mechanism(s) associated with the expression of fungal enzyme genes involved in plant biomass degradation.

Regulatory factor X (RFX) family proteins regulate both cellular differentiation and the cell cycle [10] and contain an RFX DNA-binding domain belonging to the winged-helix subfamily of helix-turn-helix proteins [11]. Since the identification of RFX1 in mammals, several conserved members from yeast to humans, as well as filamentous fungi, have been isolated $[10,12,13]$, including RTX1-7 in humans [14], Snf1-activating kinase 1 (Sak1) in Schizosaccharomyces pombe [15], cephalosporin C regulator 1 (CPCR1) in Acremonium chrysogenum [16], RfxA in Talaromyces marneffei (formerly Penicillium marneffei) [12], and PcRFX1 in Penicillium rubens (formerly Penicillium chrysogenum) [13]. Among these, RTX1-7 is critical for the development of serious human diseases [14], and Sak1 promotes mitotic exit mediated by cAMP-dependent protein kinase [15]. Moreover, RfxA in T. marneffei controls mycelial growth and morphogenesis by regulating cell-division events [12], and PcRFX1 regulates the expression of $\beta$-lactam-biosynthesis genes [13]. However, the regulation of RFX proteins in plant biomass-degrading enzyme production in filamentous fungi, including Talaromyces spp., remains unknown.

Talaromyces pinophilus 1-95 isolated from ploughed soil in China can produce highly active calcium-independent amylase and integrative cellulase [2], both potentially applicable to plant biomass biorefining. Recently, the $T$. pinophilus 1-95 genome was sequenced [3]. In the current study, we screened and identified novel TFs that regulate the expression of amylase and cellulase genes in T. pinophilus through comparative transcriptome profiling and genetic analyses. Here, we describe a key regulatory gene, TpRfx 1 (Talaromyces pinophilus $R f x 1, T P 06218$ ), encoding an RFX protein that directly regulates the expression of amylase and cellulase genes.

\section{Results}

\section{Seven novel TFs regulate amylase production in $T$. pinophilus}

To screen candidate genes that regulate amylase production in T. pinophilus 1-95, we preformed comparative analyses of transcriptomes from strain 1-95 grown in media in the presence and absence of glucose or soluble starch as the sole carbon source. The results identified 33 candidate genes exhibiting expression levels higher than that of creA in strain 1-95 with glucose relative to strain 1-95 in the absence of a carbon source or amyR in strain 1-95 with starch relative to strain 1-95 with glucose or in the absence of a carbon source (Additional file 1: Table S1).

The 33 candidate genes were then subjected to knockout experiments following homologous recombination in the parental strain derived from the wild-type 1-95 strain through deletion of TpKu70, which is involved in non-homologous end joining [17]. Ultimately, 30 deletion mutants were successfully constructed and validated with PCR (Additional file 2: Figure S1A-W) using specific primers (Additional file 3: Table S2), with a targeting rate 


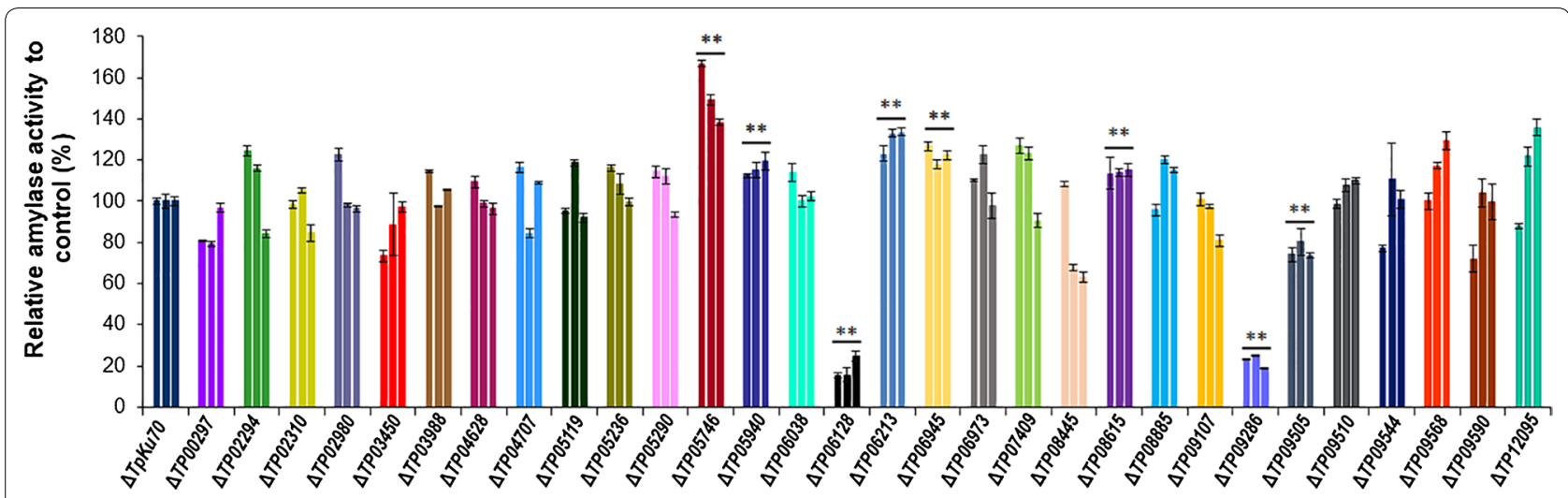

Fig. 1 The amylase activities of crude enzymes produced by deletion mutants of the candidate regulatory genes grown with soluble corn starch used as the sole carbon source for 5 -days post-inoculation. All experiments were performed independently in triplicate. ${ }^{* *} P \leq 0.01$ and ${ }^{*} P \leq 0.05$ between the deletion mutants and the parental strain $\triangle T p K u 70$ by Student $t$ test

of $91 \%$. Measurement of amylase production revealed that eight of the deletion mutants, including the known $\triangle T p A m y R$, showed significant changes in amylase production $(P<0.05$, Student $t$ test $)$ ranging from 18.5 to $151.4 \%$ of amylase production of $\triangle T p K u 70$ (Fig. 1). Of the genes deleted in these eight mutants, seven genes (TP05746, TP05940, TP06128, TP06213, TP06945, TP08615, and TP09505) were here firstly reported to be involved in amylase production in T. pinophilus (Table 1). Interestingly, $\triangle T P 06128$ showed the $75.4 \%$ to $84.5 \%$ decrease in amylase activity as compared with $\Delta T p K u 70$ when grown in the presence of soluble starch, suggesting TP06128 as the most important regulatory gene among

Table 1 The found novel regulatory genes in this study regulating amylase production in T. pinophilus 1-95

\begin{tabular}{|c|c|c|c|}
\hline Gene ID & $\begin{array}{l}\text { GenBank } \\
\text { accession } \\
\text { number }\end{array}$ & $\begin{array}{l}\text { InterPro } \\
\text { annotation }^{a}\end{array}$ & Domain description \\
\hline \multirow[t]{2}{*}{ TP05746 } & MH447996 & IPR001138 & Zinc finger, Zn2Cys6 type \\
\hline & & IPR007219 & Fungal_Trans \\
\hline \multirow[t]{2}{*}{ TP05940 } & MH447994 & IPR01 1991 & Winged helix repressor \\
\hline & & & DNA-binding domain \\
\hline \multirow[t]{2}{*}{ TP06128 } & MH447992 & IPR003150 & RFX \\
\hline & & & DNA-binding domain \\
\hline \multirow[t]{2}{*}{ TP06213 } & MH447995 & IPR001138 & Zinc finger, Zn2Cys6 type \\
\hline & & IPR007219 & Fungal_Trans \\
\hline \multirow[t]{2}{*}{ TP06945 } & MH447993 & IPR001138 & Zinc finger, Zn2Cys6 type \\
\hline & & IPR007219 & Fungal_Trans \\
\hline \multirow[t]{2}{*}{ TP08615 } & MH447990 & IPR001138 & Zinc finger, Zn2Cys6 type \\
\hline & & IPR007219 & Fungal_Trans \\
\hline \multirow[t]{2}{*}{ TP09505 } & MH447991 & IPR001138 & Zinc finger, Zn2Cys6 type \\
\hline & & IPR007219 & Fungal_Trans \\
\hline
\end{tabular}

a IPR InterPro database (http://www.ebi.ac.uk/interpro/scan.html) the seven genes. Therefore, the gene TP06128 was chosen for further investigation.

To exclude the possibility of gene insertion at multiple sites in the $\triangle T p K u 70$ genome by the TP06128-knockout cassette, Southern hybridization analysis was performed using specific probes (Additional file 3: Table S2) to ensure accurate products (Additional file 2: Fig. S1X). A complementary strain harboring TP06128 was subsequently constructed and confirmed with PCR using specific primers (Additional file 4: Figure S2 and Additional file 3: Table S2).

\section{TP06128 encodes an RFX protein containing an RFX DNA-binding domain}

The TP06128-encoded protein comprises 861 amino acids, with SMART analysis (http://smart.embl-heide lberg.de/) revealing the presence of an RFX DNA-binding domain (PF02257; $E$ value, 9.1e-28) between residue positions 240-317 (Fig. 2a). Additionally, BlastP (https ://blast.ncbi.nlm.nih.gov/Blast.cgi) analysis indicated that the protein TP06128 shares $92 \%$ and $27 \%$ sequence identity with RfxA from T. marneffei 2161 (ABG56532.1) and Sak1 from S. pombe $972 \mathrm{~h}^{-}$(P48383), respectively. TP06128 was subsequently re-designated as TpRfx1 (Tp is the abbreviation of fungal species name Talaromyces pinophilus).

Phylogenetic analysis indicated conservation of TpRfx 1 (TP06128) and its homologs in filamentous fungi, and specifically in Talaromyces $\mathrm{sp}$. The proteins in this tree were divided into six clusters (I-VI), which included those identified in filamentous fungi (I and II), yeast (III and IV), and mammals (V and VI). RFX1 proteins from filamentous fungi were close in evolutionary relationship to those in yeast, followed by those in mammals, and more distant from those in Drosophila (Fig. 2b). 


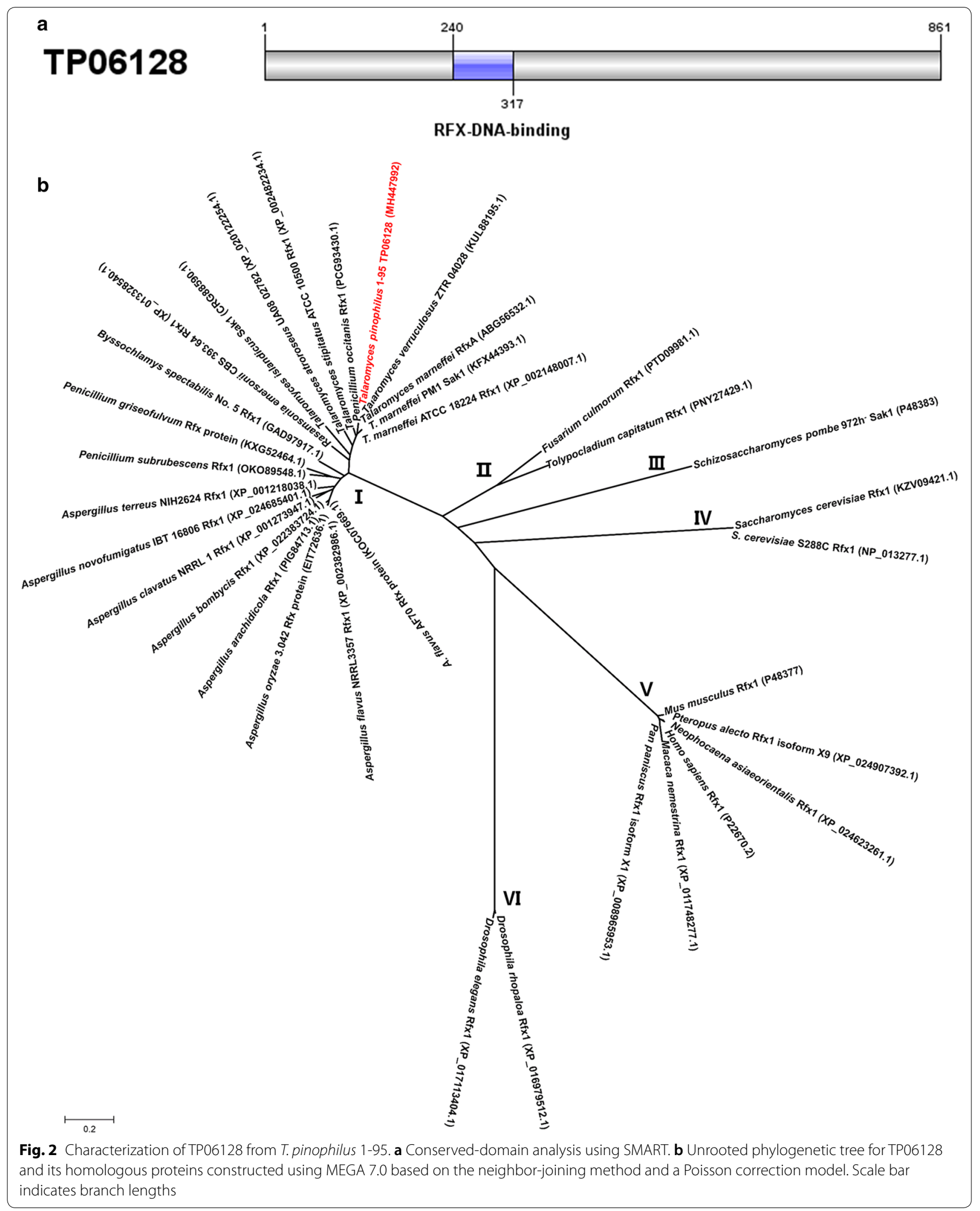


TpRfx 1 is required for amylase and cellulase production in T. pinophilus under specific induction conditions

To investigate the regulatory roles of $\mathrm{TpRfx} 1$ in promoting plant biomass degradation by amylases and cellulases in $T$. pinophilus, the $\Delta T p R f x 1$ strain, complementary strain $C T p R f x 1$, and parental strain $\Delta T p K u 70$ were transferred into fresh medium containing soluble corn starch (SCS) or wheat bran plus Avicel (WA) for a 5-day culture following a 24-h pre-culture in glucose medium, and their amylase and cellulase activities were measured. The results indicated that $\Delta T p R f x 1$ lost $77.6 \%$ to $87.3 \%$ amylase activity relative to that observed in $\triangle T p K u 70$ $(P<0.01$, Student $t$ test $)$ under SCS induction, whereas CTpRfx1 displayed similar amylase activity as that observed in $\triangle T p K u 70$ (Fig. 3a).

Evaluation of cellulase activity showed that the filter paper cellulase (FPase), carboxymethylcellulase (CMCase), $p$-nitrophenyl- $\beta$-cellobiosidase (pNPCase),
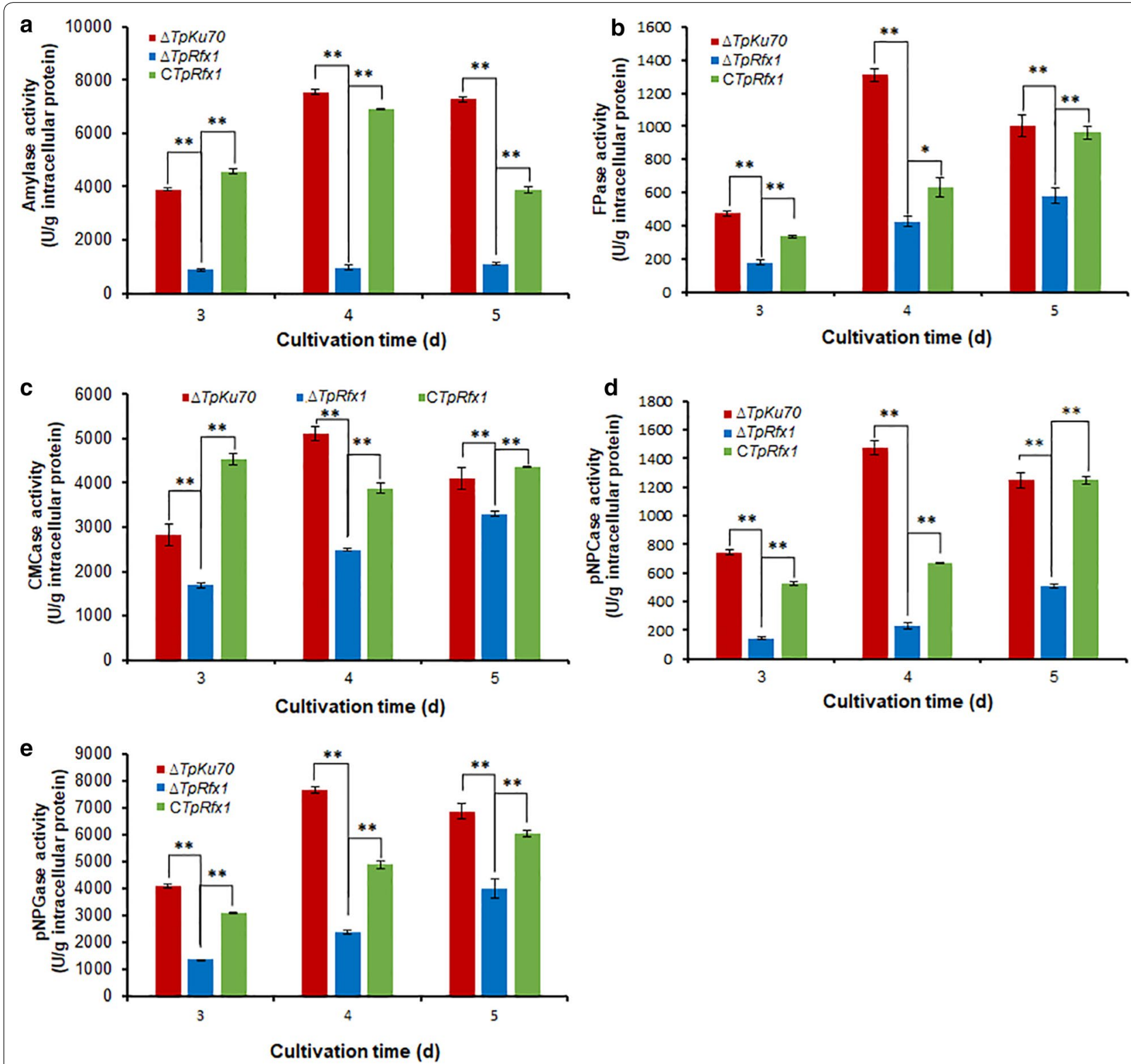

Fig. 3 Activities of crude enzymes produced by $\triangle T p R f x 1, C T p R f \times 1$ and $\triangle T p K u 70$. Crude enzymes were collected from fungal strains grown on SCS or WA for $3-5$ days at $28^{\circ} \mathrm{C}$ after shifting from glucose. All experiments were performed independently in triplicate. ${ }^{*} P<0.01$ and ${ }^{*} P<0.05$ between the deletion mutant $\triangle T P 06128$ and the parental strain $\triangle T$ TKU 70 or complementary strain $C T p R f \times 1$ by Student $t$ test. a Amylase activity. $\mathbf{b}$ Filter paper cellulase (FPase) activity. $\mathbf{c}$ Carboxy methyl cellulase (CMCase) activity. $\mathbf{d} p$-nitrophenyl- $\beta$-cellobiosidase (pNPCase) activity. e $p$-nitrophenyl- $\beta$-glucop yranosidase (pNPGase) activity 
and $\quad p$-nitrophenyl- $\beta$-glucopyranosidase (pNPGase) activities of $\Delta T p R f x 1$ were reduced by $42.4 \%$ to $67.4 \%$, $19.9 \%$ to $40.3 \%, 59.2 \%$ to $84.3 \%$, and $41.7 \%$ to $69.0 \%$ $(P<0.05$, Student $t$ test), respectively, relative to the activity observed in $\triangle T p K u 70$ under WA induction. As expected, all cellulase activities in CTpRfx1 were similar to that in the parental strain (Fig. 3b-e).

\section{TpRfx 1 controls $T$. pinophilus sporulation and growth}

To evaluate the effect of TpRfx 1 on T. pinophilus phenotype and growth, $\Delta T p R f x 1$, CTpRfx 1 , and $\Delta T p K u 70$ were incubated on solid plates containing WA as the sole carbon source, with PDA plates used as a control. Asexual spores produced by strains $\Delta T p R f x 1, C T p R f x 1$, and $\Delta T p K u 70$ on plates were quantitatively analyzed. The results revealed that $\Delta T p R f x 1$ produced only $36.6 \%$ of the spores generated from $\triangle T p K u 70$ when grown on WA plates for 8 days, whereas $\Delta T p R f x 1$ barely produced spores when grown on PDA plates over the same cultivation time. Additionally, CTpRfx1 exhibited similar levels of spores on both WA and PDA plates as the $\triangle T p K u 70$ (Fig. 4a). Microscopic investigation showed that $\triangle T p R f x 1$ mycelia did not sporulate when grown on both PDA and WA plates for $80 \mathrm{~h}$, whereas $\triangle T p K u 70$ and $C T p R f x 1$ formed sporangium and produced asexual spores (Fig. 4b).

To determine whether TpRfx1 affects T. pinophilus cell growth, growth curves for both $\Delta T p R f x 1$ and $\Delta T p K u 70$ were compared following inoculation into medium containing glucose or SCS as the sole carbon source. $\Delta T p R f x 1$ accumulated similar amounts of mycelial biomass as that by $\Delta T p K u 70$ (Fig. 4c) in glucose medium, whereas the mycelial biomass of $\Delta T p R f x 1$ was slightly lower than that of $\triangle T p K u 70$ in SCS medium (Fig. 4d), suggesting that lack of TpRfx1 affected the utilization of starch by T. pinophilus.

\section{TpRfx1 regulates the expression of amylase and cellulase genes in T. pinophilus}

To investigate whether $\mathrm{TpRf} x 1$ transcriptionally regulates the expression of amylase genes in T. pinophilus grown on SCS, real-time quantitative reverse transcription PCR (RT-qPCR) was employed, with $\Delta T p K u 70$ as a control under the same cultivation conditions. The transcription levels of all 24 amylase genes in T. pinophilus 1-95 [3], including five $\alpha$-amylase genes (TP03368, TP03580, TP04014, TP07411, and TP09288), five glucoamylase genes (TP04225, TP07482, TP09267, TP09287, and TP12319), $13 \alpha$-glucosidase genes (TP09781, TP011464, TP12265, TP03913, TP00071, TP05786, TP00293, TP00938, TP01354, ТP03337, ТP04013, ТP04937, and TP05120), and a gene encoding a 1,4- $\alpha$-glucan-branching enzyme (TP03955) were measured at $48 \mathrm{~h}$ after shifting from glucose to SCS. The expression of each tested amylase gene in the $\Delta T p K u 70$ as the control was set to $100 \%$. The results showed that the transcripts of 15 genes were significantly altered in $\Delta T p R f x 1$, including five upregulated by 2.2 - to 9.3 -fold and 10 downregulated by $52.0 \%$ to $97.8 \%$ (Fig. $5 \mathrm{a}$ ), relative to that in the $\triangle T p K u 70$.

Furthermore, seven amylase genes (TP04014, TP09288, TP09267, TP00293, TP01354, TP04013, and TP05120) exhibiting substantial reduction in expression relative to the control were selected to investigate dynamic regulation by TpRfx1. Among these, TP04014 and TP09267 were predicted to encode the key $\alpha$-amylase Amy13A and glucoamylase Amy15A, respectively. Their transcription levels subsequently were measured at 12,24 , and $48 \mathrm{~h}$ after the shift from glucose to SCS. The results indicated that only three genes (TP04014, TP01354, and TP05120) exhibited from 31.6 to $81.4 \%$ reduced expression in $\triangle T p R f x 1$ at $12 \mathrm{~h}$ as compared with that in $\triangle T p K u 70$. Conversely, TP09288, TP09267, and TP00293 showed 1.4- to 3.8-fold elevations in transcript levels in $\triangle T p R f x 1$ at $12 \mathrm{~h}$ relative to the control. By contrast, at $24 \mathrm{~h}$, all genes, except TP01354, showed upregulated expression ranging from 2.4- to 5.7 -fold in $\triangle T p R f x 1$ relative to the control. The transcript levels of all genes were significantly lower in $\triangle T p R f x 1$ as compared with those in $\triangle T p K u 70$ at $48 \mathrm{~h}$ (Fig. 5b).

Additionally, we evaluated TpRfx 1 regulation of key cellulase genes, including TP09412 (cbh1), TP08514 (eg1), and TP05820 (bgl1), in T. pinophilus grown on WA and at 12, 24, and $48 \mathrm{~h}$ after the shift from glucose. TpRfx1 deletion resulted in significant reduction in both TP09412 and TP08514 transcripts at 12 and $24 \mathrm{~h}(P<0.01$, Student $t$ test $)$, whereas no changes were observed at $48 \mathrm{~h}$. The expression of TP05820 in $\Delta T p R f x 1$ was increased 3.7 -fold at $12 \mathrm{~h}$, decreased $89.1 \%$ at $24 \mathrm{~h}$, and the same as levels observed in $\Delta T p K u 70$ at 48 h (Fig. 5c).

\section{TpRfx 1 binds to the promoter regions of genes encoding plant biomass-degrading enzymes in vitro}

To confirm whether TpRfx1 directly or indirectly regulates targeted gene expression, in vitro binding experiments were performed using an electrophoretic mobility shift assay (EMSA). The predicted DNA-binding domain of $\mathrm{TpRfx} 1\left(\mathrm{TpRfx} 1_{190-376}\right)$ was expressed in Escherichia coli, and the recombinant protein TRXHis-S-tagged TpRfx $1_{190-376}$ was subsequently purified using a nickel-affinity column. The 6-FAM-tagged DNA fragments $(\sim 1000 \mathrm{bp})$ located in the promoter regions of the five selected target genes, including two amylase genes (TP04014 and TP09267), three cellulase genes (TP09412, TP08514, and TP05820), were PCR amplified using specific primer pairs (Additional file 3: Table S2). EMSA experiments revealed shifted bands 


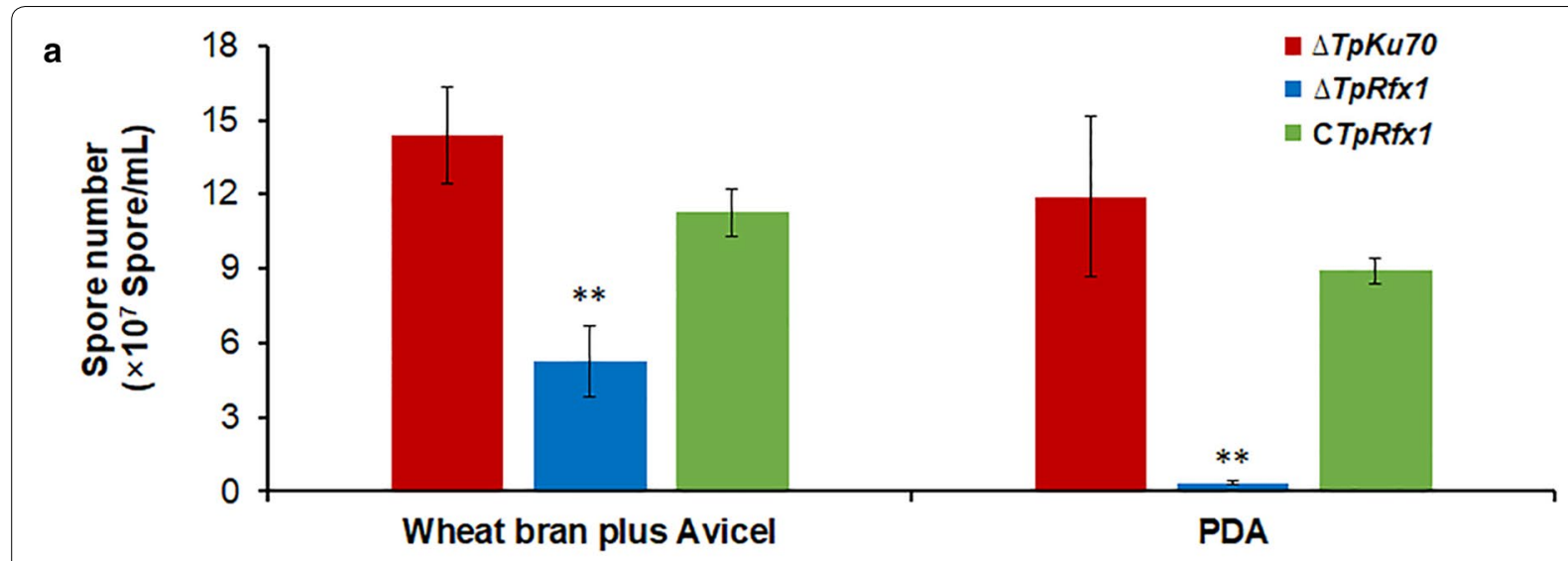

b
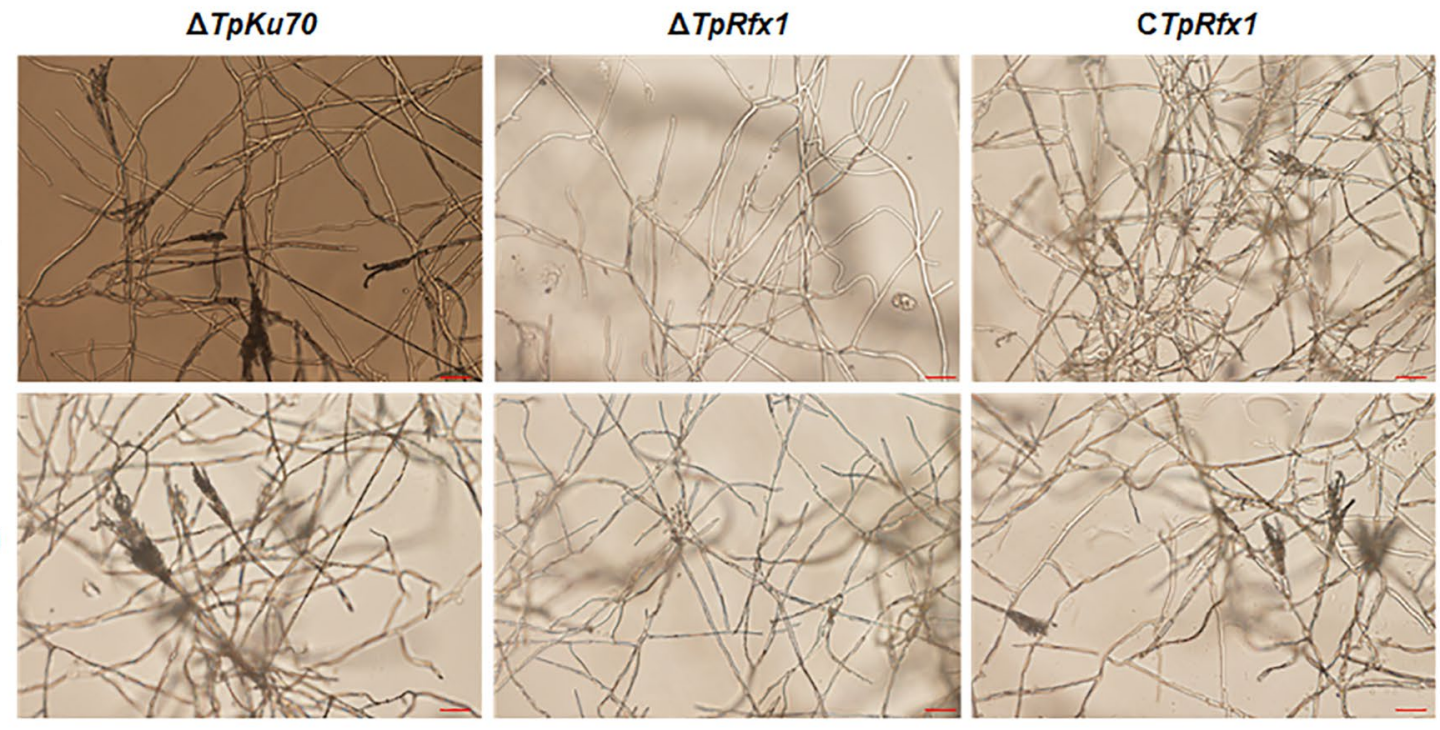

Wheat bran plus Avicel
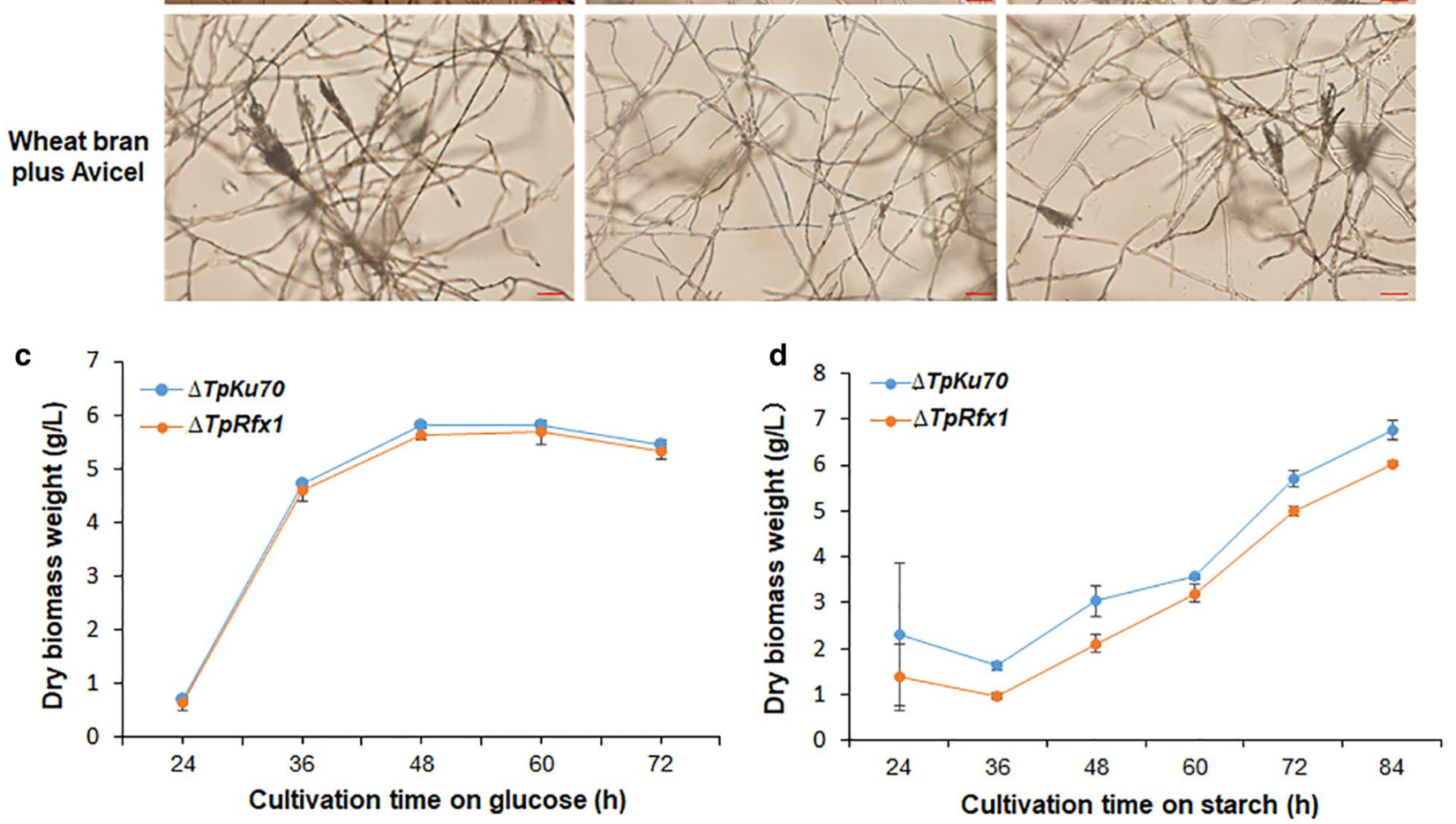

Fig. 4 Phenotypic analyses of $\triangle T p R f x 1, C T p R f x 1$ and $\triangle T p K u 70$. a Quantitative analysis of conidiation on plates containing PDA or WA incubated at $28^{\circ} \mathrm{C}$ for 8 days. ${ }^{* *} P<0.01$ between $\triangle T p R f x 1$ and $\triangle T p K u 70$ by Student $t$ test. b Microscopic investigation of mycelial sporulation on plates containing PDA or WA. Fungal strains were cultivated at $28^{\circ} \mathrm{C}$ for $80 \mathrm{~h}$. $\mathbf{c}, \mathbf{d}$ Growth curves of $\triangle T p R f x 1$ and $\triangle T p K u 70$ in medium containing glucose and SCS as the sole carbon source, respectively. In $\mathbf{a}, \mathbf{c}, \mathbf{d}$, independent experiments were performed in triplicate 

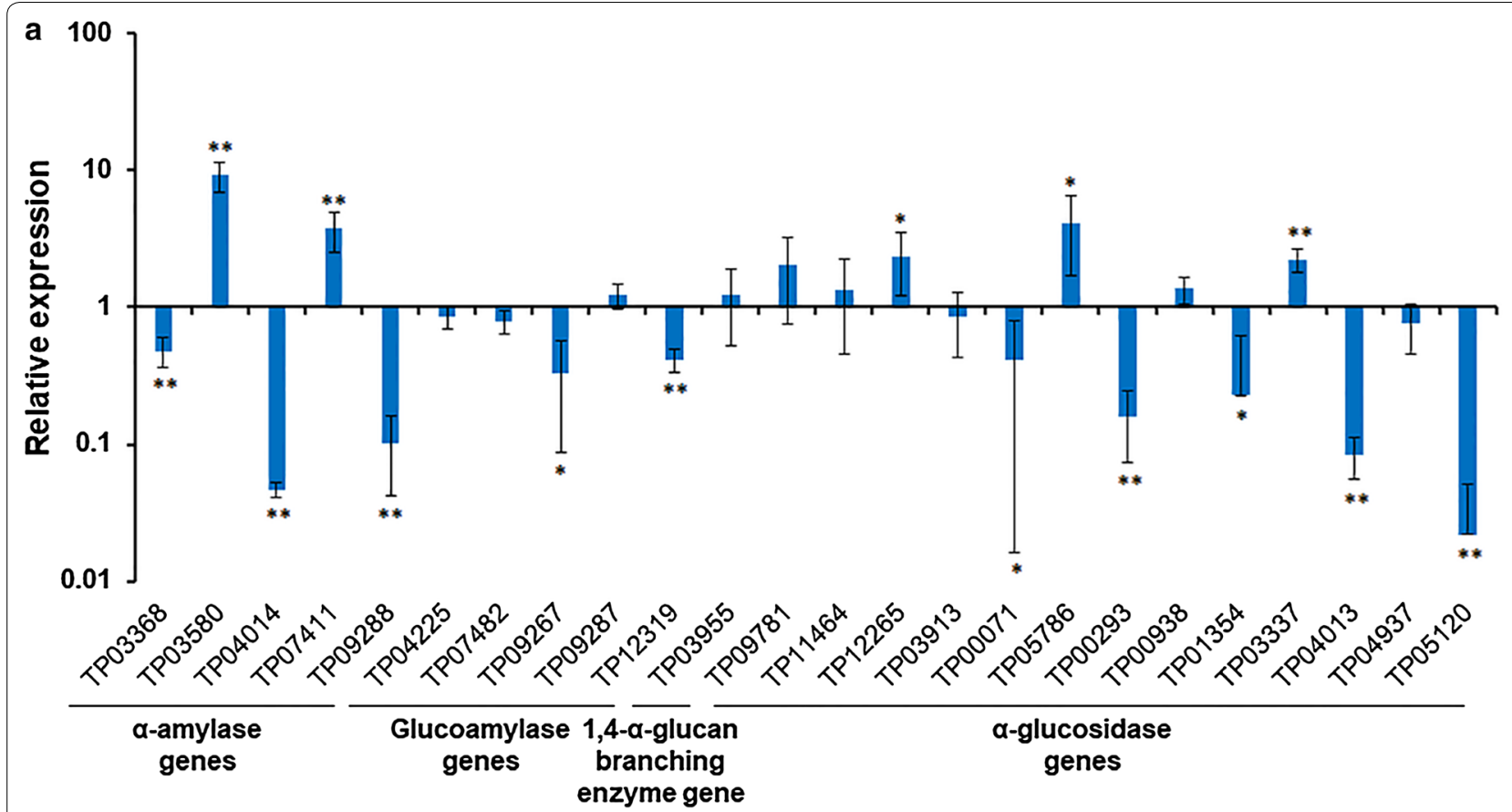

b

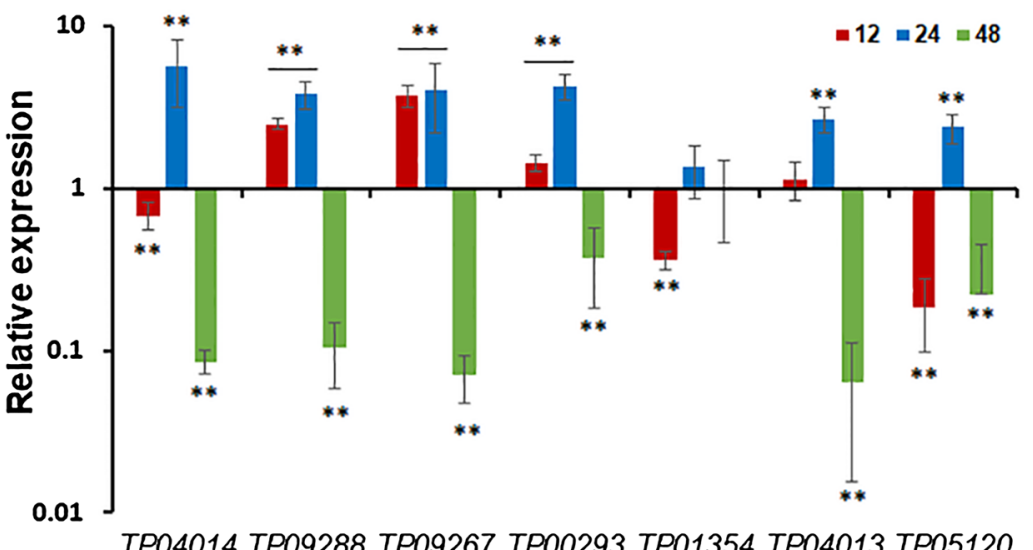

c

$\begin{array}{ccc}\begin{array}{c}\alpha \text {-amylase } \\ \text { genes }\end{array} & \begin{array}{c}\text { Glucoamylase } \\ \text { genes }\end{array} & \begin{array}{c}\alpha \text {-glucosidase } \\ \text { genes }\end{array}\end{array}$

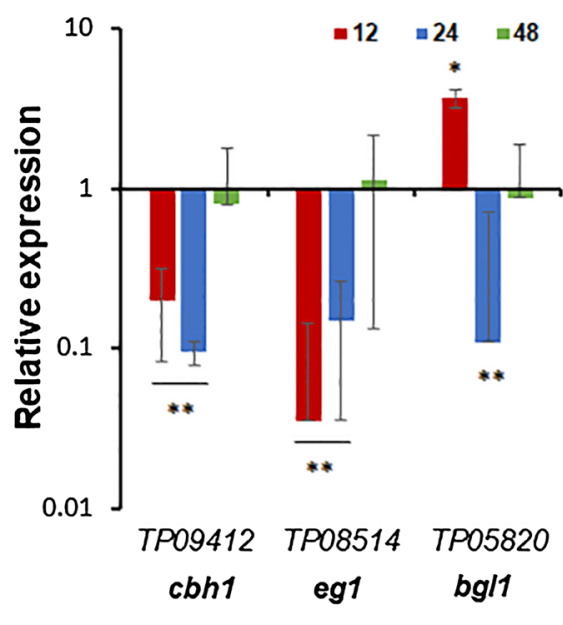

Fig. 5 Regulation of amylase and cellulase gene expression by $T p R f x 1$ in T.pinophilus. Expression levels of the tested genes in the $\Delta T p R f \times 1$ were normalized against the parental strain $\triangle T p K u 70$. ${ }^{*} P \leq 0.01$ and ${ }^{*} P \leq 0.05$ between $\triangle T p R f x 1$ and $\triangle T p K u 70$ by Student $t$ test. All experiments were independently performed in triplicate. a Expression levels of 24 amylase genes, including five a-amylase genes, five glucoamylase genes, one gene encoding a 1,4-a-glucan-branching enzyme, and 13 a-glucosidase genes. Samples were prepared from fungal strains grown on medium containing SCS for $48 \mathrm{~h}$ after shifting from glucose. $\mathbf{b}$ Expression levels of seven amylase genes, including two a-amylase genes, two glucoamylase genes, and three a-glucosidase genes, under SCS induction. Transcriptional levels were measured by RT-qPCR at three time points (12, 24, and $48 \mathrm{~h})$ after shifting from glucose. $\mathbf{c}$ Expression levels of three cellulase genes, including one cellobiohydralase gene (cbh 1), one endo- $\beta$-1,4-glucanase gene (eg1), and $\beta$-1,4-glucosidase gene (bg/1), under WA induction. Transcriptional levels were measured with RT-qPCR at three time points (12, 24, and $48 \mathrm{~h}$ ) after shifting from glucose

representing TpRfx $1_{190-376}$-DNA complexes in all mixtures of TpRfx $1_{190-376}$ and the promoter regions of the tested genes. Moreover, we observed increase in band size along with increases in $\mathrm{TpRfx} 1_{190-376}$ mass used in the gels $(0.5-2.0 \mu \mathrm{g})$. Subsequently, we performed competitive EMSA using the same DNA fragments lacking the FAM tag, with results revealing weaker binding affinities and smaller band sizes associated 
with the shifted bands. As expected, no shifted bands were observed in mixtures comprising $\mathrm{TpRf} \times 1_{190-376}$ and the promoter region for $\beta$-tubulin gene or bovine serum albumin (BSA), the purified TRX-His-S fusion protein, and any tested target genes (Figs. 6, 7). These results suggested that $\operatorname{TpRfx} 1_{190-376}$ specifically bound all five tested DNA sequences from the promoter regions of the amylase and cellulase genes in vitro.

\section{The DNA-binding sequence targeted by TpRfx 1}

TpRfx1 regulates amylase and cellulase gene expression by directly binding to their promoter regions. To determine the targeted DNA sequence in the promoter regions, a consensus RFX-binding sequence

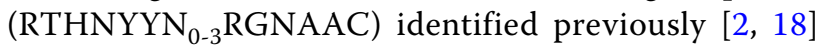
was used to search $1-\mathrm{kb}$ regions of the $5^{\prime}$ untranslated regions of the tested amylase genes (TP04014 and TP09267) and cellulase genes (TP05820, TP08514, and TP09412). The results identified at least one similar binding sequence $\left(\mathrm{TN}_{3} \mathrm{DN}_{3} \mathrm{GNAAC}\right)$ in each target gene, with the "T" nucleotide and the "GNAAC" sequence highly conserved (Fig. 8a).

This putative DNA-binding sequence targeted by TpRfx1 was used to search the genome of T. pinophilus 1-95 [3] using the MEME suite 4.12.0 (http://memesuite.org/index.html), with results indicating that $1-\mathrm{kb}$ regions of the promoters for 2169 genes contained at least one instance of this putative TpRfx1-binding sequence. Pathway classification revealed that these target genes are mainly involved in metabolism (xenobiotics biodegradation and metabolism, carbohydrate metabolism, and amino acid metabolism) and signal transduction (Fig. 8b).

\section{Discussion}

In this study, we screened and identified novel TFs regulating amylase and cellulase gene expression in T. pinophilus through comparative transcriptome and molecular genetic analyses. Comparative transcriptomics combined with genetic analyses are considered efficient methods for screening novel TFs, as described in the identification of the TFs RCA-1, PoxCxrA, PoxCxrB, and PoxNsdD in Neurospora crassa and P. oxalicum [19, 20]. In the present study, seven novel TFs were identified as regulating amylase production in T. pinophilus under SCS induction, with most of these containing a Zn2Cys6 domain. Furthermore, we identified TpRfx1 belonging to the RFX TF family as an essential positive regulator for amylase gene expression. RFX1 proteins are evolutionarily conservative according to their RFX DNA-binding domain and exist broadly in eukaryotes from yeast to humans. The RFX1 protein regulates the immune response in mammals and is response to infection by human hepatitis B virus, as well as cell-differentiation events in fission yeast [10]. Recently, RFX1 proteins were identified as being involved in controlling the cell growth and morphogenesis of the filamentous fungi T. marneffei [12], as well as the biosynthesis of secondary catabolites, such as $\beta$-lactam, cephalosporin $\mathrm{C}$, and penicillin, in $P$. chrysogenum and $A$. chrysogenum $[13,21]$. In the present study, we expanded the regulatory roles of RFX1 proteins in amylase and cellulase production in the filamentous fungus T. pinophilus for the first time, suggesting diversity in the functions of conserved RFX1 proteins as regulators of gene expression.

TpRfx 1 regulates amylase and cellulase gene expression by directly binding to their promoter regions, which harbor at least one putative DNA-binding site specific for this TF. The putative TpRfx1 DNA-binding sequence $\left(\mathrm{TN}_{3} \mathrm{DN}_{3}\right.$ GNAAC) shares the nucleotide "T" and the five nucleotides "GNAAC" with the consensus RFX-binding

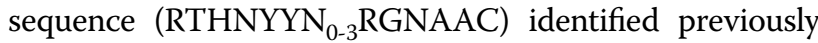
$[12,18]$, implying that these nucleotides are required for interactions between RFX1 TFs and their target genes.

In addition to the regulatory roles of RFX proteins RFX1 and CPCR1 reported in T. marneffei and A. chrysogenum $[12,21], T p R f x 1$ positively regulated hyphae growth and conidiation of T. pinophilus. Moreover, TpRfx1 deletion led to reduced transcription of important amylase and cellulase genes, resulting in the decreased production of extracellular amylases or cellulases to degrade SCS or cellulose, thereby leading to impaired cell differentiation and conidiation.

Talaromyces pinophilus strain 1-95 secretes extracellular enzymes in a carbon source-dependent manner. For example, high-yield amylase production, but not cellulase production, is observed in the presence of SCS medium (data not shown). Here, we found that TpRfx1 regulated the expression of different genes encoding plant biomass-degrading enzymes, such as amylases and cellulases, dependent on the type of carbon source used for induction. Our findings suggested the existence of a novel TpRfx1-mediated real-time network involved in regulating amylase and cellulase gene expression in $T$. pinophilus in the presence of SCS and WA, respectively (Figs. 5, 9). In the presence of SCS, TpRfx1 initiated the expression of $\alpha$-amylase (TP04014/Amy13A) and inhibited glucoamylase (TP09267/Amy15A) expression during the early induction stage. Subsequently, transcription of both amylase genes was repressed by TpRfx1. During the later stage, TpRfx1 functioned as an activator to promote the expression of both genes. Interestingly, the transcription of important cellulase genes was not regulated by TpRfx1 in the presence of SCS. By contrast, in the presence of WA, the expression of both CBH (TP09412/cbh1) and EG (TP08514/eg1) was enhanced by TpRfx1, whereas 

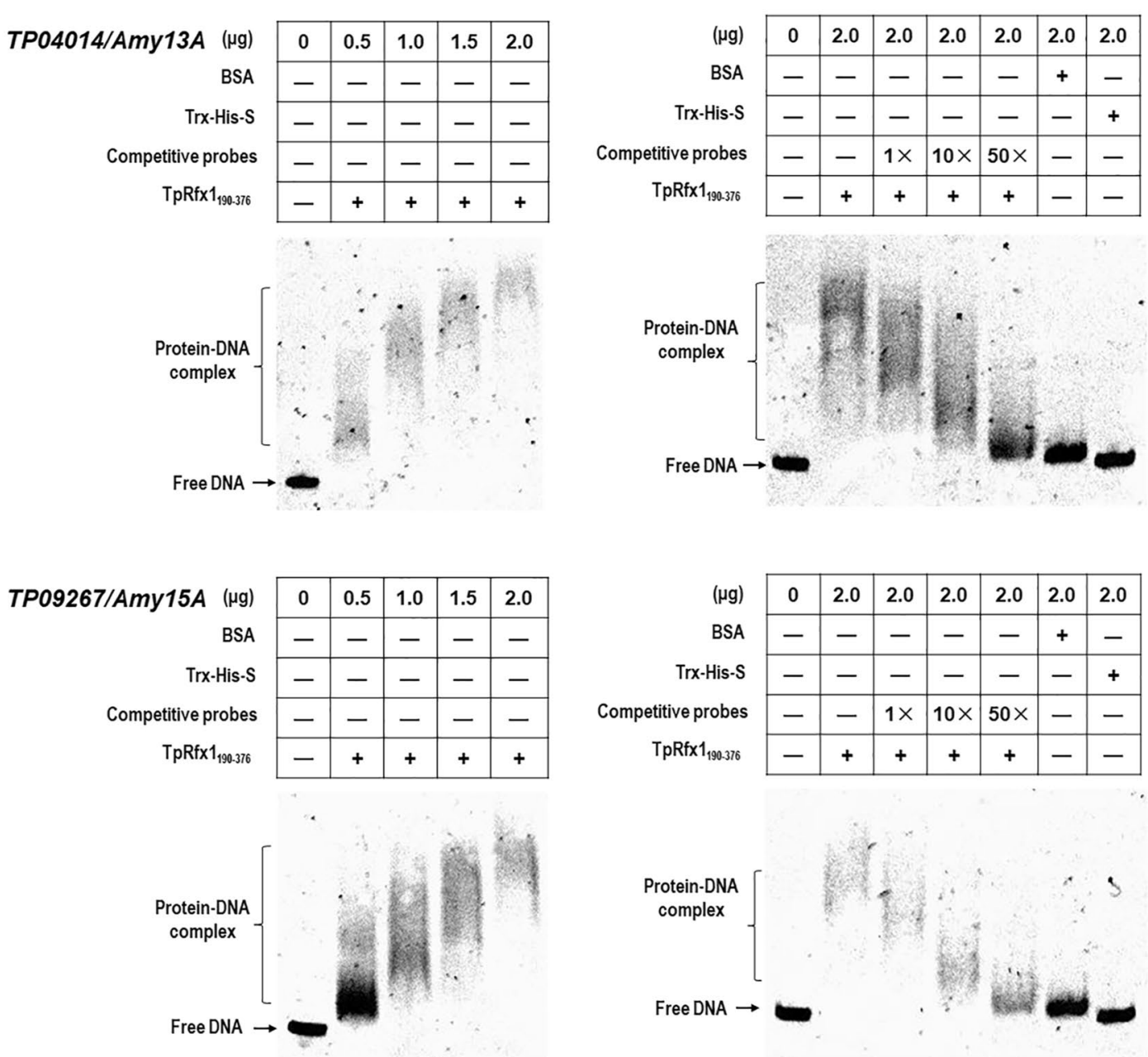

\begin{tabular}{|c|c|c|c|c|c|c|c|}
\hline$\beta$-tubulin gene & 0 & 0.5 & 1.0 & 1.5 & 2.0 & 2.0 & 2.0 \\
\hline BSA & - & - & - & - & - & + & - \\
\hline Trx-His-S & - & - & - & - & - & - & + \\
\hline Competitive probes & - & - & - & - & - & - & - \\
\hline $\operatorname{TpRfx} 1_{190-376}$ & - & + & + & + & + & - & - \\
\hline
\end{tabular}

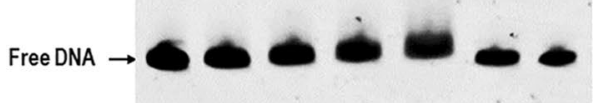

Fig. 6 EMSA revealing interactions between TpRfx1 DNA-binding domain and the promoter regions of amylase genes. The indicated amounts of purified TpRfx ${ }_{190-367}$ were mixed with about 150 ng of FAM-labeled EMSA probes. EMSA probes lacking the FAM label and the promoter region of $\beta$-tubulin gene were used for competitive EMSA and as a negative control, respectively. BSA alone and TRX-His-S from E. coli cells containing the empty vector $\mathrm{pET}-32 \mathrm{a}(+)$ were used as controls 

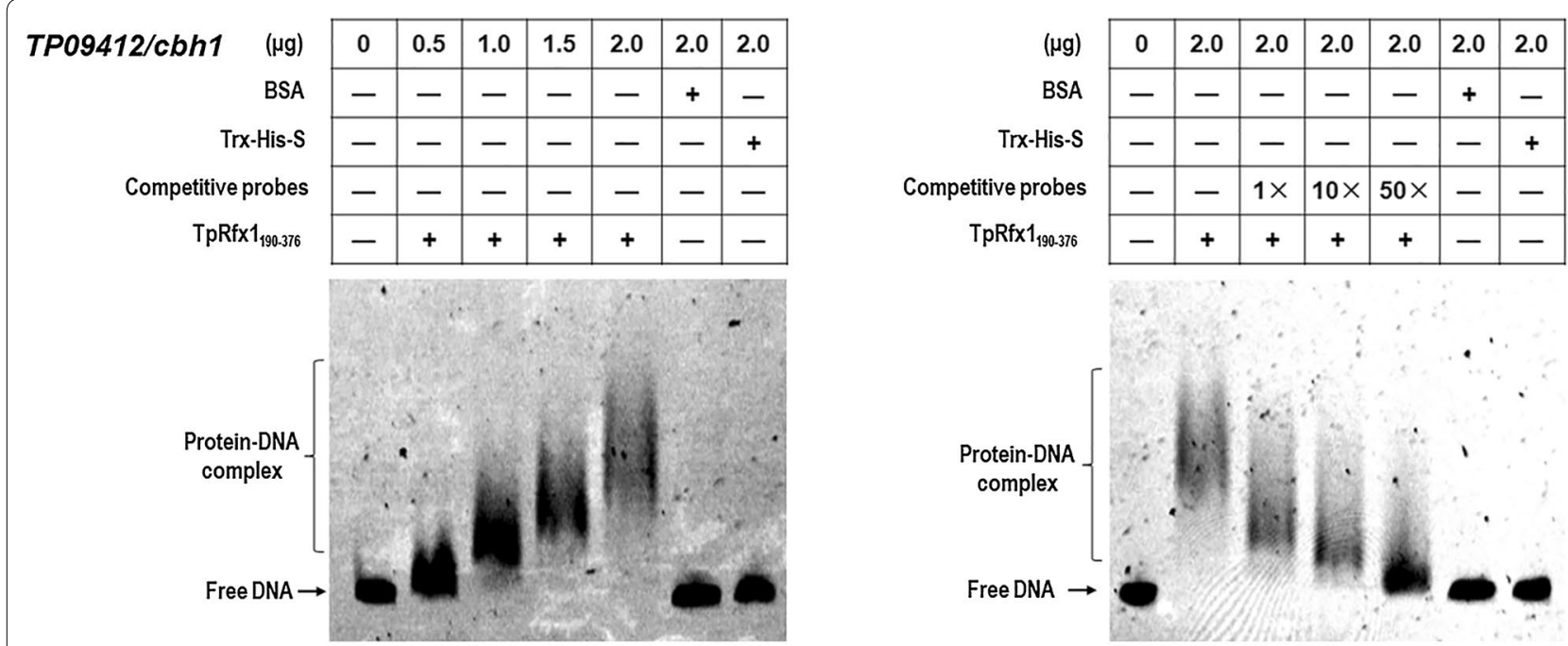

\begin{tabular}{|c|c|c|c|c|c|c|c|}
\hline \multirow[t]{2}{*}{ TP08514/eg1 } & 0 & 0.5 & 1.0 & 1.5 & 2.0 & 2.0 & 2.0 \\
\hline & - & - & - & - & - & + & - \\
\hline Trx-His-S & - & - & - & - & - & - & + \\
\hline Competitive probes & - & - & - & - & - & - & - \\
\hline $\operatorname{TpRfx} 1_{190-376}$ & - & + & + & + & + & - & - \\
\hline
\end{tabular}

\begin{tabular}{|c|c|c|c|c|c|c|c|}
\hline$(\mu \mathrm{g})$ & 0 & 2.0 & 2.0 & 2.0 & 2.0 & 2.0 & 2.0 \\
\hline BSA & - & - & - & - & - & + & - \\
\hline Trx-His-S & - & - & - & - & - & - & + \\
\hline Competitive probes & - & - & $1 \times$ & $10 x$ & $50 x$ & - & - \\
\hline $\operatorname{TpRfx} 1_{190.376}$ & - & + & + & + & + & - & - \\
\hline
\end{tabular}
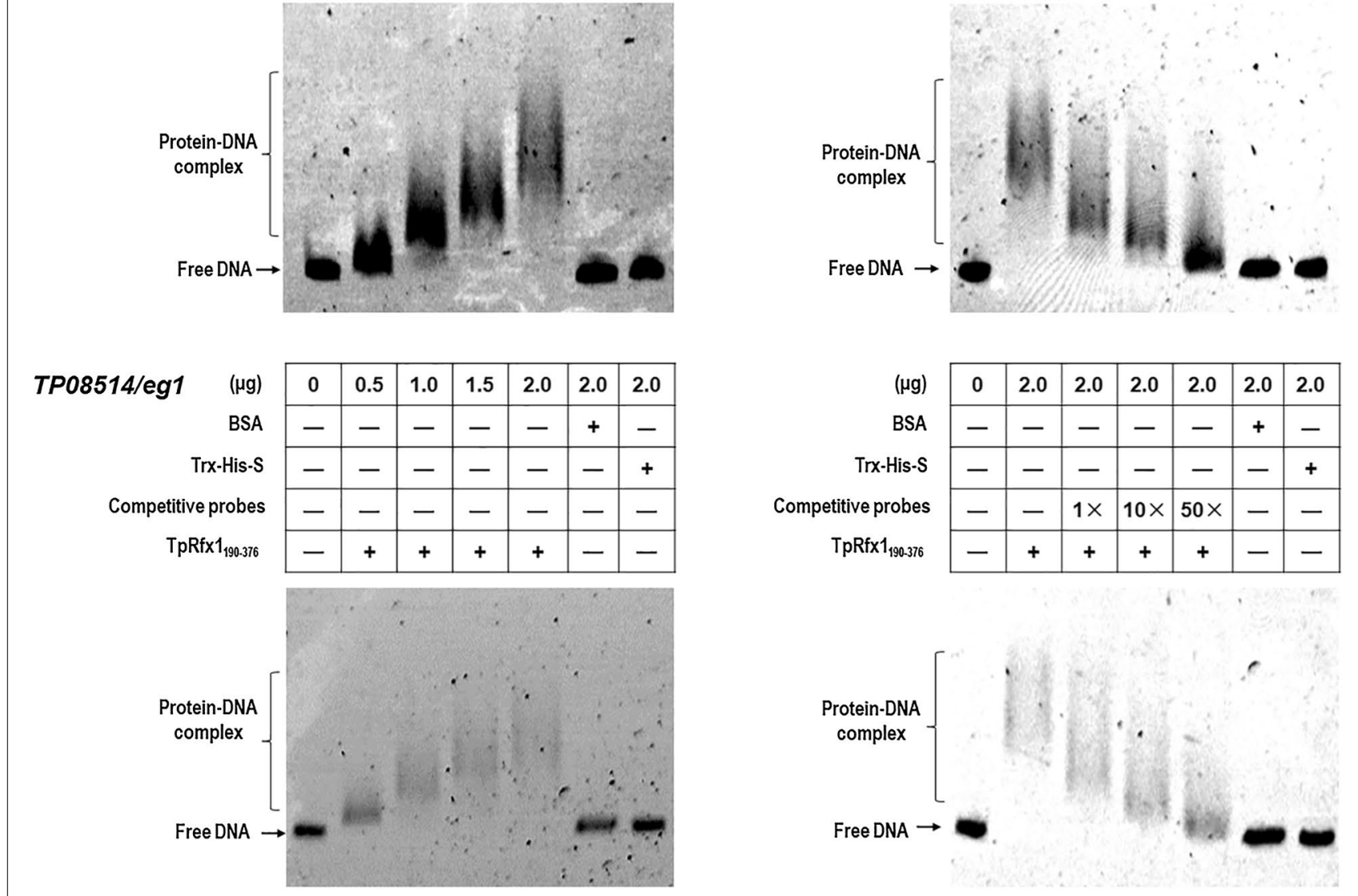

\begin{tabular}{|c|c|c|c|c|c|c|c|c|}
\hline \multirow[t]{2}{*}{ TP05820/bg/1 } & $(\mu \mathrm{g})$ & 0 & 0.5 & 1.0 & 1.5 & 2.0 & 2.0 & 2.0 \\
\hline & BSA & - & - & - & - & 一 & + & - \\
\hline \multicolumn{2}{|c|}{ Trx-His-S } & - & - & - & - & - & - & + \\
\hline \multirow{2}{*}{\multicolumn{2}{|c|}{$\begin{array}{r}\text { Competitive probes } \\
\qquad \mathrm{TpRfx} 1_{190.376}\end{array}$}} & - & - & - & - & - & - & - \\
\hline & & - & + & + & + & + & - & - \\
\hline
\end{tabular}

\begin{tabular}{|c|c|c|c|c|c|c|c|}
\hline$(\mu \mathrm{g})$ & 0 & 2.0 & 2.0 & 2.0 & 2.0 & 2.0 & 2.0 \\
\hline BSA & - & - & - & - & - & + & - \\
\hline Trx-His-S & - & - & - & - & - & - & + \\
\hline Competitive probes & - & - & $1 \times$ & $10 x$ & $50 \times$ & - & - \\
\hline $\operatorname{TpRfx}_{190-376}$ & - & + & + & + & + & - & - \\
\hline
\end{tabular}
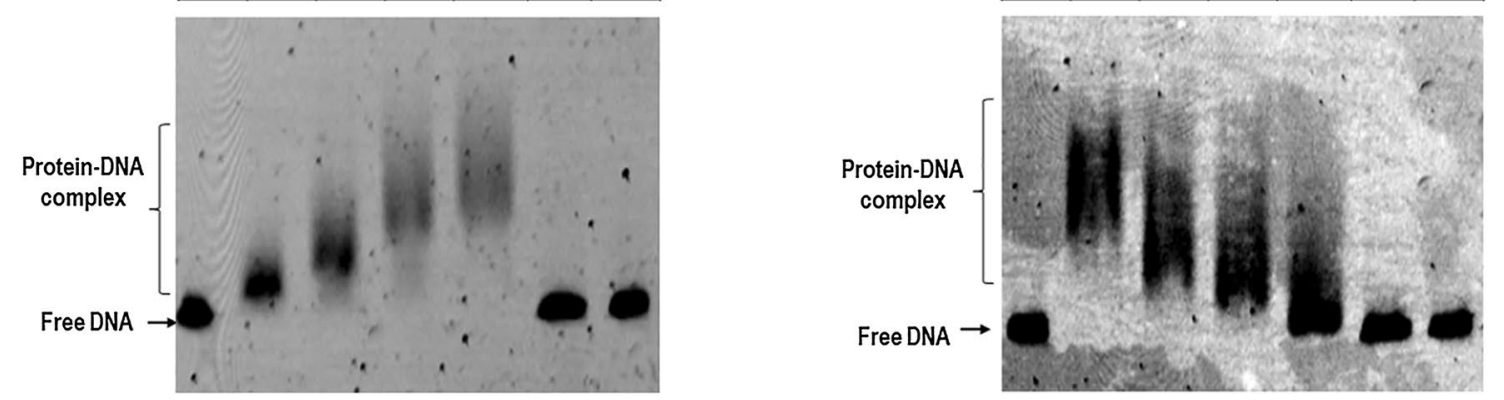
(See figure on previous page.)

Fig. 7 TpRfx 1 binding to the promoter regions of cellulase genes. The indicated amounts of purified TpRfx $1_{190-367}$ were mixed with about $150 \mathrm{ng}$ of FAM-labeled EMSA probes. EMSA probes lacking the FAM label and the promoter region of $\beta$-tubulin gene were used for competitive EMSA and as a negative control, respectively. BSA alone and TRX-His-S from E. coli cells containing the empty vector pET-32a(+) were used as controls

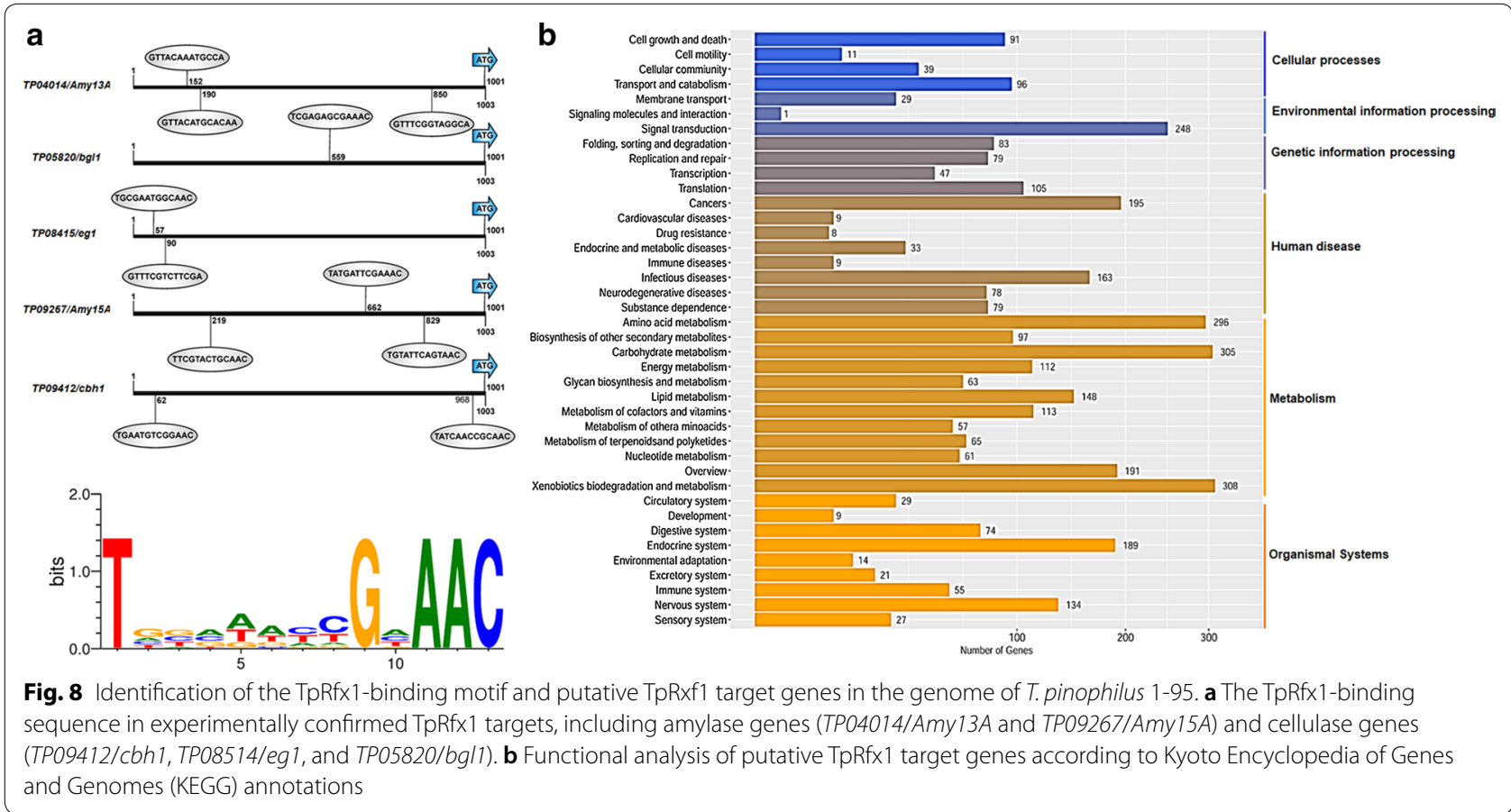

BGL (TP05820/bgl1) expression was repressed at 12-h post-induction. Subsequently, at 24-h post-induction, TpRfx1 enhanced the transcription of all the three cellulase genes; however, at later stages (i.e., 48-h post-induction), TpRfx1 did not regulate the expression of these three cellulase genes.

In S. pombe, the TpRfx1 homologous protein Sak1 controls cAMP-dependent protein kinase-mediated exit from the mitotic cell cycle [15]. In P. oxalicum, the G proteincAMP pathway positively regulates the expression of amylase genes, such as amy15A, in the presence of either starch or cellulose while negatively regulating cel7A-2 expression during early induction by controlling the expression of the $A m y R$ [22]. Recently, Zhang et al. [17] reported that $T p A$ $m y R$ (TP09286) positively regulates important amylase genes in T. pinophilus, which agrees with the regulatory roles reported for AmyR in other filamentous fungi, such as P. oxalicum [6] and Aspergillus sp. [23].

Additionally, another TpRfx1 homologous protein, Crt1, can bind regions of DNA-damage-response genes, including RNR2-4 and HUG1, to recruit the chromatinrepression complex SSN6-TUP1 and histone deacetylases to maintain these genes in a repressed state during methyl methanesulfonate induction of Saccharomyces cerevisiae $[24,25]$. Conversely, Crt1 also facilitates the recruitment of the chromatin-remodeling complexes SWI/SNF and TFIID to promote chromatin remodeling and full assembly of the preinitiation complex to activate ribonucleotide reductase gene expression [26-28]. SptAda-Gcn 5 acetyltransferase complex subunit-encoding genes, such as Gcn5 and Ada2, activates the transcription of cellulase genes in $T$. reesei and regulates mycelial growth $[29,30]$. Additionally, the SWI/SNF complex subunit-encoding gene HepA (Swi6 in S. cerevisiae) is a positive regulator required for cellulase and amylase gene expression in P. oxalicum [31], and Snf2 expression is significantly upregulated in $T$. reesei strain $\Delta C r e 1$ and possibly involved in cellulase gene repression by Cre1 [32]. However, these regulatory mechanisms in $T$. pinophilus remained unclear. To augment our findings, additional investigation is necessary to elucidate the regulatory mechanisms associated with TpRfx1 regarding its mediation of cellulase and amylase gene expression in T. pinophilus under starvation conditions. 


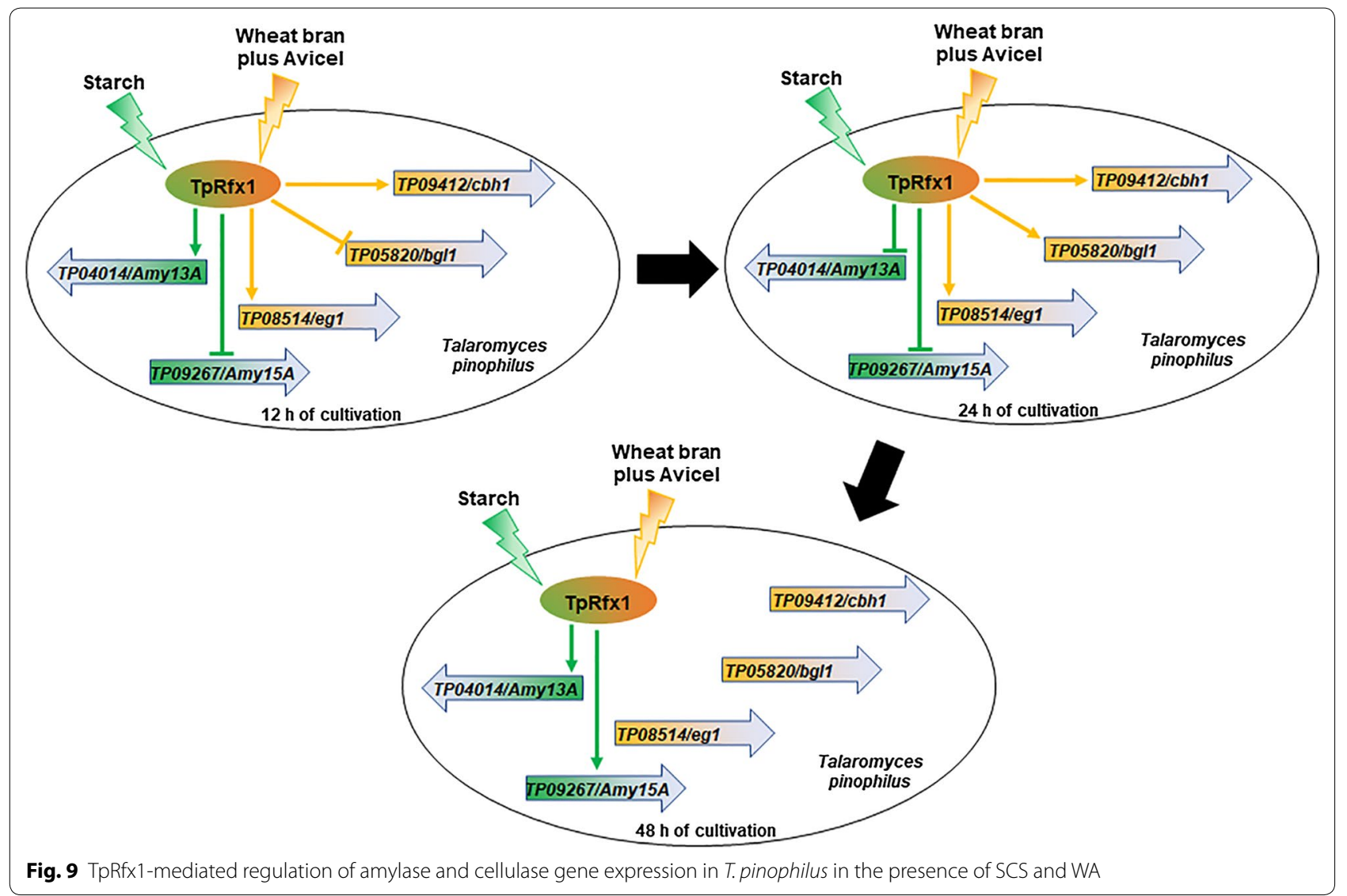

\section{Conclusions}

Altogether, in this study, we expanded the novel regulatory roles of the RFX proteins in the regulation of genes encoding plant biomass-degrading enzymes including amylase and cellulase in T. pinophilus for the first time, which provides a novel insight into deeply understanding of molecular regulatory mechanism of the expression of functional enzyme genes at transcriptional level in fungi and a potential target for genetic engineering processes.

\section{Methods}

\section{Microbial strains and culture conditions}

Fungal strains used in this study included the parental strain $\triangle T p K u 70$, the deletion mutants for the 30 candidate genes (Additional file 1: Table S1), and the complementary strain $C T p R f x 1$. Fungal strains were maintained on PDA plates at $4{ }^{\circ} \mathrm{C}$. For sporulation and mycelial growth (for DNA extraction), PDA medium and liquid complete medium [(g/L) D-glucose 10, peptone 2 , yeast extract 1 , acid-hydrolyzed casein 1 , and $50 \mathrm{~mL} 20 \times$ nitrate-containing $\mathrm{NaNO}_{3} 120, \mathrm{KCl} 10.4$, $\mathrm{MgSO}_{4} \cdot 7 \mathrm{H}_{2} \mathrm{O}$ 10.4, $\mathrm{KH}_{2} \mathrm{PO}_{4} 30.4$ ( $\mathrm{pH}$ 6.5)] were inoculated and subsequently incubated at $28{ }^{\circ} \mathrm{C}$ for 6 days [33]. For enzymatic activity measurement and RT-qPCR analyses, approximately $1 \times 10^{8}$ fresh spores were pregrown in $100 \mathrm{~mL}$ glucose medium at $28{ }^{\circ} \mathrm{C}$ for $24 \mathrm{~h}$. Certain amounts of mycelia were harvested, transferred into standard liquid medium $(\mathrm{SLM})[(\mathrm{g} / \mathrm{L})$ tryptone 5 , $\mathrm{KH}_{2} \mathrm{PO}_{4} 3,\left(\mathrm{NH}_{4}\right)_{2} \mathrm{SO}_{4} 2.5, \mathrm{MgSO}_{4} \cdot 7 \mathrm{H}_{2} \mathrm{O} 0.2, \mathrm{CaCl}_{2} 0.13$, and $\mathrm{FeSO}_{4}$ 0.0255] containing 1\% (w/v) SCS (SigmaAldrich, St. Louis, MO, USA) or $1 \%(\mathrm{w} / \mathrm{v})$ wheat bran plus 1\% (w/v) Avicel (Sigma-Aldrich) and incubated at $28{ }^{\circ} \mathrm{C}$ for $2-4$ days. For mycelial-biomass determination, SLM containing $1 \%(\mathrm{w} / \mathrm{v})$ D-glucose was used and cultivated at $28{ }^{\circ} \mathrm{C}$ for $84 \mathrm{~h}$. For phenotypic analyses, solid SLM containing $1 \%(\mathrm{w} / \mathrm{v}) \mathrm{SCS}$ was cultivated at $28^{\circ} \mathrm{C}$ for 8 days, with PDA used as a control. E. coli Trans1-T1 and DE3 were used as cloning and expression hosts, respectively, and cultured at $37^{\circ} \mathrm{C}$ in Luria-Bertani medium.

\section{Total DNA and RNA extraction}

Total fungal DNA and RNA were extracted from mycelia harvested from PDA plates or liquid media, as previously described [33]. Briefly, harvested mycelia were ground into flour in liquid nitrogen and lysed using lysate reagent [20 mM sodium acetate trihydrate, $40 \mathrm{mM}$ Tris $-\mathrm{HCl}$, $10 \mathrm{mM}$ ethylenediaminetetraacetic acid, and $1 \%$ sodium dodecyl sulfate ( $\mathrm{pH}$ 8.0)]. Total DNA was separated from 
the lysed suspension after removing protein with phenol-chloroform and isopropanol precipitation. Additionally, a TRIzol RNA kit (Life Technologies, Carlsbad, CA, USA) was used to extract total RNA according to manufacturer instructions.

\section{Construction of deletion cassettes and T. pinophilus transformation}

Deletion cassettes were constructed using double-joint PCR, as described previously [17]. Each deletion cassette contained $\sim 2 \mathrm{~kb}$ of the $5^{\prime}$ - and $3^{\prime}$-flanking regions of the target gene and $2.8 \mathrm{~kb}$ of the benomyl-resistance gene (benA) and was amplified using corresponding primer pairs (Additional file 3: Table S2). The amplified product was introduced into $\Delta T p K u 70$ protoplasts [33] and transformants were confirmed by PCR or Southern hybridization analysis using specific primers (Additional file 3: Table S2).

\section{Mutant complementation}

Complementation of $\Delta T p R f x 1$ was performed according to previously described methods [20]. Briefly, a genecomplementary cassette was constructed through fusion PCR and comprised the upstream and downstream DNA sequences of $T p R f x 1$, the predicted termination sequence of TP06064, and the bleomycin-resistance gene (ble), all of which were PCR amplified using corresponding primer pairs (Additional file 3: Table S2 and Additional file 4: Fig. S2). The resulting cassette was introduced into $\Delta T p R f x 1$ protoplasts, and complementary strains were confirmed with PCR using specific primer pairs (Additional file 3: Table S2).

\section{Southern hybridization}

The $\Delta T p R f x 1$ strain was confirmed with Southern hybridization analysis according to previously described methods [33]. The genomic DNA of the $\Delta T p R f x 1$ strain was extracted and digested with SacI (TaKaRa Bio Inc., Dalian, China), and the generated DNA fragments were separated on $0.8 \%$ agarose gels, followed by transfer to a Hybond- ${ }^{+}$nylon membrane (GE Healthcare Ltd., Little Chalfont, UK). DIG-high detection starter kit (Life Technologies) was used to investigate the hybridized bands using a DIG-high-labeled DNA probe amplified using the primers indicated in Additional file 3: Table S2.

\section{Enzyme activity assay and determination of intracellular protein concentration}

Amylase and cellulase (FPase, CMCase, xylanase, pNPCase, and pNPGase) activities were determined as previously described [17, 33]. Briefly, suitably diluted crude enzyme solution was added to $0.1 \mathrm{M}$ citratephosphate buffer ( $\mathrm{pH} 5.0$ ) containing $1 \%$ of different substrates, including SCS, filter paper, carboxymethyl cellulose, and xylan, and incubated at $55{ }^{\circ} \mathrm{C}$ for $30 \mathrm{~min}$ and $50{ }^{\circ} \mathrm{C}$ for 60,30 and $10 \mathrm{~min}$, respectively. The generated reducing sugars were determined using 3,5-dinitrosalicylic acid method [34] at $540 \mathrm{~nm}$. One unit of enzymatic activity $(\mathrm{U})$ was defined as the amount of enzyme required to produce $1 \mu \mathrm{mol}$ of reducing sugar per min from the reaction substrates.

In addition, $p$-nitrophenyl- $\beta$-D-cellobioside (pNPC) and $p$-nitrophenol- $\alpha$-D-glucopyranoside (pNPG) were used as the substrates for measurement of pNPCase and pNPGase activities, respectively. A $140 \mu \mathrm{L}$ mixture containing $14 \mu \mathrm{L}$ of $25 \mathrm{mM}$ pNPC or pNPG solution, $116 \mu \mathrm{L}$ of citrate buffer $(100 \mathrm{mM}, \mathrm{pH} 5.0)$, and $10 \mu \mathrm{L}$ of diluted crude cellulase was incubated at $50{ }^{\circ} \mathrm{C}$ for $15 \mathrm{~min}$, and then $70 \mu \mathrm{L}$ of sodium carbonate $(0.4 \mathrm{M})$ was added into the mixture to stop the reaction. The produced $p$-nitrophenol was measured at $410 \mathrm{~nm}$, and $1 \mathrm{U}$ of enzymatic activity $(\mathrm{U})$ was defined as the amount of enzyme that produced $1 \mu \mathrm{mol}$ of $p$-nitrophenol per min from the appropriate substrate. Triplicate independent experiments were performed for each sample.

Determination of intracellular protein concentration in fungal mycelia was conducted according to previously described methods [35]. The collected mycelia were milled in liquid nitrogen and added to protein extract buffer. Protein concentration was measured based on the Bradford method.

\section{Determination of dry biomass weight}

Fresh spore suspensions at concentrations of $1.0 \times 10^{8}$ spores/mL were inoculated into $100 \mathrm{~mL}$ of glucose or starch liquid medium, respectively, and cultivated at $28{ }^{\circ} \mathrm{C}$ for $24 \mathrm{~h}$ to $84 \mathrm{~h}$. The hypha was collected by vacuum suction filter and then dried at $50{ }^{\circ} \mathrm{C}$ to a constant weight.

\section{RT-qPCR analysis}

The PrimeScript RT reagent kit (TaKaRa) was used for RT-qPCR analysis according to manufacturer instructions. Each PCR was performed in a final volume of $20 \mu \mathrm{L}$, including $10 \mu \mathrm{L}$ of SYBR Premix ExTaq II, $0.8 \mu \mathrm{L}$ of $10 \mu \mathrm{M}$ forward primer, $0.8 \mu \mathrm{L}$ of $10 \mu \mathrm{M}$ reverse primer, $2.0 \mu \mathrm{L}$ of cDNA, and $6.4 \mu \mathrm{L}$ of sterile water. Reaction procedures were as follows: initial denaturation for $2 \mathrm{~min}$ at $95{ }^{\circ} \mathrm{C}$, followed by 40 cycles of $10 \mathrm{~s}$ at $95^{\circ} \mathrm{C}$ and $30 \mathrm{~s}$ at $61{ }^{\circ} \mathrm{C}$. The fluorescence signal was measured at the end of each extension step at $80^{\circ} \mathrm{C}$. Relative expression levels of the tested genes were calculated according to previously described methods [17]. 


\section{Expression of the DNA sequence encoding the putative DNA-binding domain of TpRfx 1 and purification of the translated product}

The DNA sequence encoding the putative DNA-binding domain TpRfx $1_{190-376}$ was amplified with PCR using the primer pairs TP06128-domain-F and TP06128-domainR (Additional file 3: Table S2). The DNA fragment was digested by NotI and HindIII and cloned into vector pET32a $(+)$ digested with the same restriction endonucleases. The generated pET32a-TpRfx $1_{190-376}$ was introduced into E. coli Trans-DE3 cells and after isopropyl- $\beta-\mathrm{d}-$ thiogalactopyranoside induction, the recombinant proteins fused with TRX, His, and $\mathrm{S}$ tags were purified using TALON metal-affinity resin (Clontech, Palo Alto, CA, USA). The strain containing the empty vector $\mathrm{pET} 32 \mathrm{a}(+)$ was cultivated as a control.

\section{In vitro EMSA}

EMSA was performed as previously described [20]. Briefly, approximately 1-kb DNA fragments from the promoter regions of the tested genes were used as probes following amplification by PCR using specific primers (Additional file 3: Table S2). FAM-tagged EMSA probes were mixed with various amounts $(0-2.0 \mu \mathrm{g})$ of TpRfx $1_{190-367}$ in binding buffer $[0.1 \mathrm{mg} / \mathrm{mL}$ BSA, $20 \mathrm{mM}$ Tris- $\mathrm{HCl}$ (pH 8.0), 5\% glycerol, $50 \mathrm{mM} \mathrm{KCl,} 1 \mathrm{mM}$ DTT, and $2 \mu \mathrm{g}$ sheared salmon sperm DNA] and incubated for $20 \mathrm{~min}$. Polyacrylamide Tris-acetic acid-EDTA gel electrophoresis and the Bio-Rad ChemiDoc MP imaging system (Bio-Rad Laboratories, Hercules, CA, USA) were used for the separation and detection of protein-DNA complexes, respectively. EMSA probes without FAM labels were used for competitive EMSA. BSA alone and TRX-His-S from $E$. coli cells transformed with the empty vector pET-32a $(+)$ were used as controls.

\section{Phylogenetic analysis}

TpRfx1 and its homologous proteins were phylogenetically analyzed using MEGA 7.0 software [36]. A phylogenetic tree was constructed based on the neighbor-joining method and a Poisson correction model. In this process, the bootstrap values were calculated when 1000 replicates were established.

\section{Statistical analysis}

All experimental data involving enzyme production and gene transcription were statistically analyzed using Microsoft Excel (Office 2016; Microsoft, Redmond, WA, USA). Significance analyses among samples were performed by Student $t$ test, and a $P<0.05$ was considered significant.

\section{Additional files}

Additional file 1: Table S1. List of candidate regulatory genes for regulating amylase production of T. pinophilus.

Additional file 2: Figure S1. Confirmation analysis of the deletion mutants of 23 candidate genes in T. pinophilus mutant $\triangle T p K u 70$ as the parental strain. A-W. PCR confirmation analysis of (A) $\triangle T P 00297,(B)$ $\triangle T P 02310,(C) \triangle T P 02980,(\mathrm{D}) \triangle T P 03450,(\mathrm{E}) \triangle T P 03988,(\mathrm{~F}) \triangle T P 05236,(\mathrm{G})$ $\triangle T P 05746,(\mathrm{H}) \triangle T P 05940$, (I) $\triangle T P 06128$, (J) $\triangle T P 06213,(\mathrm{~K}) \triangle T P 06945,(\mathrm{~L})$ $\triangle T P 06973,(\mathrm{M}) \triangle T P 07409,(\mathrm{~N}) \triangle T P 08445,(\mathrm{O}) \triangle T P 08615,(\mathrm{P}) \triangle T P 08885,(\mathrm{Q})$ $\triangle T P 09107,(\mathrm{R}) \triangle T P 09505,(\mathrm{~S}) \triangle T P 09510,(\mathrm{~T}) \triangle T P 09544,(\mathrm{U}) \triangle T P 09568,(\mathrm{~V})$ $\triangle T P 095904,(W) \triangle T P 12095$. Line M: 1-kb DNA marker, Lanes 1-3: three transformants constructed for each candidate gene, Lane 4: $\triangle P O X K U 70$, Lane 5: $\mathrm{ddH}_{2} \mathrm{O}$. The PCR products for each deletion mutant included the production of each target gene (Top), the production of the fragment on the left of the target gene (Middle) and the production of the fragment on the right of the target gene. X. Southern hybridization confirmation of the mutant $\triangle T P 06128$. The probe was amplified from the $5^{\prime}$-flanking sequence of TP06128. Lane M: 1-kb DNA marker, Lane 1: genomic DNA from $\triangle P$ PoxKu70 as the control, Lanes 2-4, genomic DNA from three transformants of $\triangle T P 06128$.

Additional file 3: Table S2. The primers used in this study.

Additional file 4: Figure S2. Complementation of the mutant $\triangle T P 06128$. A. TP06128 complementary DNA cassette integrated into genome of $\triangle T P 06128$ through homologous recombination. B-D. PCR confirmation of the complementary strain. PCR products were amplified with specific primer pairs TP06128-V-F/TP06128-V-R (B), CTP06128-L-F/TP06064ter-R (C) and TP06064ter-F/CTP06128-R-R (D), respectively. Lane M: 1-kb DNA marker, Lanes 1-3: genomic DNA from three transformants of complementary strain, Lane +: genomic DNA from the $\triangle T p K u 70$ as the positive control, and Lane -: genomic DNA from the $\triangle T P 06128$ as the negative control.

\section{Abbreviations}

PDA: potato dextrose agar; SLM: standard liquid medium; EG: endo- $\beta$-1:4glucanase; $\mathrm{CBH}$ : cellobiohydrolase; $\mathrm{BGL}$ : $\beta$-glucosidase; TF: transcription factor; RFX: regulatory factor $X$; FPase: filter paper cellulase; CMCase: carboxymethylcellulase; pNPCase: $p$-nitrophenyl- $\beta$-cellobiosidase; pNPGase: $p$-nitrophenyl$\beta$-glucopyranosidase; RT-qPCR: real-time quantitative reverse transcription PCR; SCS: soluble corn starch; EMSA: electrophoretic mobility shift assay; FAM: 6-carboxyfluorescein; BSA: bovine serum albumin.

\section{Authors' contributions}

JXF designed and supervised the research, was involved in the data analysis and the preparation of the manuscript. SZ co-supervised all the research, and was involved in the analysis of all experimental data and the preparation of the manuscript. GYL performed the construction of deletion mutants, enzymatic activity tests, RT-qPCR, EMSA and was involved in the preparation of the manuscript. TZ was involved in the construction of deletion mutants. CXL performed bioinformatic analysis. LSL, FFZ and XML were involved in the preparation of experimental materials and the analysis of experimental data. All authors read and approved the final manuscript.

\section{Acknowledgements}

We thank Baoshan Chen from State Key Laboratory for Conservation and Utilization of Subtropical Agro-bioresources, Guangxi University, China for providing us with the plasmid pLPMBn containing benA gene.

\section{Competing interests}

The authors declare that they have no competing interests.

Availability of supporting data

DNA sequences are deposited on the GenBank database (Accession Numbers MH447990-MH447996). 


\section{Consent for publication}

All authors consent for publication.

\section{Ethical approval and consent to participate}

Not applicable.

\section{Funding}

This work was financially supported by the Guangxi BaGui Scholars Program Foundation (Grant No. 2011A001) to JXF, and the 'One Hundred Person' Project of Guangxi to SZ.

\section{Publisher's Note}

Springer Nature remains neutral with regard to jurisdictional claims in published maps and institutional affiliations.

Received: 9 July 2018 Accepted: 26 September 2018 Published online: 08 October 2018

\section{References}

1. Samson RA, Yilmaz N, Houbraken J, Spierenburg H, Seifert KA, Peterson SW, Varga J, Frisvad JC. Phylogeny and nomenclature of the genus Talaromyces and taxa accommodated in Penicillium subgenus Biverticillium. Stud Mycol. 2001;70:159-83.

2. Xian L, Wang F, Luo X, Feng YL, Feng JX. Purification and characterization of a highly efficient calcium-independent a-Amylase from Talaromyces pinophilus 1-95. PLOS ONE. 2015;10:e0121531.

3. Li CX, Zhao S, Zhang T, Xian L, Liao LS, Liu JL, Feng JX. Genome sequencing and analysis of Talaromyces pinophilus provide insights into biotechnological applications. Sci Rep. 2017;7:490.

4. Marín-Navarro J, Polaina J. Glucoamylases: structural and biotechnological aspects. Appl Microbiol Biotechnol. 2011:89:1267-73.

5. Wang JP, Quirk A, Lipkowski J, Dutcher JR, Clarke AJ. Direct in situ observation of synergism between cellulolytic enzymes during the biodegradation of crystalline cellulose fibers. Langmuir. 2013;29:14997-5005.

6. Li ZH, Yao GS, Wu RM, Gao LW, Kan QB, Liu M, Yang P, Liu GD, Qin YQ, Song $X$, Zhong YH, Fang X, Qu YB. Synergistic and dose-controlled regulation of cellulase gene expression in Penicillium oxalicum. PLoS Genet. 2015;11:e1005509.

7. VanKuyk PA, Benen JAE, Wösten HAB, Visser J, de Vries RP. A broader role for AmyR in Aspergillus niger: regulation of the utilisation of D-glucose or D-galactose containing oligo- and polysaccharides. Appl Microbiol Biotechnol. 2012;93:285-93.

8. Xiong YR, Zhao S, Fu LH, Liao XZ, Li CX, Yan YS, Liao LS, Feng JX. Characterization of novel roles of a HMG-box protein PoxHmbB in biomassdegrading enzyme production by Penicillium oxalicum. Appl Microbiol Biotechnol. 2018;102:3739-53.

9. Ichinose S, Tanaka M, Shintani T, Gomi K. Increased production of biomass-degrading enzymes by double deletion of creA and creB genes involved in carbon catabolite repression in Aspergillus oryzae. J Biosci Bioeng. 2018;125:141-7

10. Emery P, Durand B, Mach B, Reith W. RFX proteins, a novel family of DNA binding proteins conserved in the eukaryotic kingdom. Nucleic Acids Res. 1996:24:803-7.

11. Gajiwala KS, Chen H, Cornille F, Roques BP, Reith W, Mach B, Burley SK. Structure of the winged-helix protein hRFX1 reveals a new mode of DNA binding. Nature. 2000;403:916-21.

12. Bugeja HE, Hynes MJ, Andrianopoulos A. The RFX protein RfxA is an essential regulator of growth and morphogenesis in Penicillium marneffei. Eukaryot Cell. 2010;9:578-91.

13. Domínguez-Santos R, Martín JF, Kosalková K, Prieto C, Ullán RV, GarcíaEstrada $C$. The regulatory factor PCRFX 1 controls the expression of the three genes of $\beta$-lactam biosynthesis in Penicillium chrysogenum. Fungal Genet Biol. 2012;49:866-81.

14. Aftab S, Semenec L, Chu JSC, Chen NS. Identification and characterization of novel human tissue-specific RFX transcription factors. BMC Evol Biol. 2008;8:226.
15. Wu SY, McLeod M. The sak $1^{+}$gene of Schizosaccharomyces pombe encodes an RFX family DNA-binding protein that positively regulates cyclic AMP-dependent protein kinase-mediated exit from the mitotic cell cycle. Mol Cell Biol. 1995;15:1479-88.

16. Schmitt EK, Kuck U. The fungal CPCR1 protein, which binds specifically to $\beta$-lactam biosynthesis genes, is related to human regulatory factor $X$ transcription factors. J Biol Chem. 2000;275:9348-57.

17. Zhang T, Zhao S, Liao LS, Li CX, Liao GY, Feng JX. Deletion of TpKu70 facilitates gene targeting in Talaromyces pinophilus and identification of TpAmyR involvement in amylase production. World J Microbiol Biotechnol. 2017;33:171.

18. Zaim J, Speina E, Kierzek AM. Identification of new gene regulated by the Crt1 transcription factor, an effector of the DNA damage checkpoint pathway in Saccharomyces cerevisiae. J Biol Chem. 2005;280:28-37.

19. Wang B, Cai PL, Sun WL, Li JG, Tian CG, Ma YH. A transcriptomic analysis of Neurospora crassa using five major crop residues and the novel role of the sporulation regulator $r c a-1$ in lignocellulase production. Biotechnol Biofuels. 2015:8(1):1-15

20. Yan YS, Zhao S, Liao LS, He QP, Xiong YR, Wang L, Li CX, Feng JX. Transcriptomic profiling and genetic analyses reveal novel key regulators of cellulase and xylanase gene expression in Penicillium oxalicum. Biotechnol Biofuels. 2017:10:279.

21. Schmitt EK, Bunse A, Janus D, Hoff B, Friedlin E, Kürnsteiner H, Kück U. Winged helix transcription factor CPCR1 is involved in regulation of betalactam biosynthesis in the fungus Acremonium chrysogenum. Eukaryot Cell. 2004;3:121-34

22. Hu YB, Liu GD, Li ZH, Qin YQ, Qu YB, Song X. G protein-CAMP signaling pathway mediated by $P G A 3$ plays different roles in regulating the expressions of amylases and cellulases in Penicillium decumbens. Fungal Genet Biol. 2013;58-59:62-70

23. Zhang H, Wang S, Zhang XX, Ji W, Song FP, Zhao Y, Li J. The amyR-deletion strain of Aspergillus niger CICC2462 is a suitable host strain to express secreted protein with a low background. Microbiol Cell Fact. 2016:15:68.

24. Huang M, Zhou Z, Elledge SJ. The DNA replication and damage checkpoint pathways induce transcription by inhibition of the Crt1 repressor. Cell. 1998;94:595-605.

25. Li B, Reese JC. Ssn6-Tup1 regulates RNR3 by positioning nucleosomes and affecting the chromatin structure at the upstream repression sequence. J Biol Chem. 2001;276:33788-97.

26. Sharma VM, Li B, Reese JC. SWI/SNF-dependent chromatin remodeling of RNR3 requires TAF(II)s and the general transcription machinery. Genes Dev. 2003:17:502-15.

27. Ghosh S, Push BF. Sequential recruitment of SAGA and TFIID in a genomic response to DNA damage in Saccharomyces cerevisiae. Mol Cell Biol. 2011;31(1):190-202.

28. Zhang $\mathrm{H}$, Reese JC. Exposing the core promoter is sufficient to activate transcription and alter coactivator requirement at RNR3. Proc Natl Acad Sci USA. 2007;104:8833-8.

29. Xin Q, Gong YJ, Lv XX, Chen GJ, Liu WF. Trichoderma reesei histone acetyltransferase Gcn5 regulates fungal growth, conidiation, and cellulase gene expression. Curr Microbiol. 2013:67:580-9.

30. Zheng FL, Gao YL, Lv XX, Wang L, Li CY, Zhang WX, Chen GJ, Liu WF. A copper-responsive promoter replacement system to investigate gene functions in Trichoderma reesei: a case study in characterizing SAGA genes. Appl Microbiol Biotechnol. 2017;101:2067-78.

31. Zhang XJ, Qu YB, Qin YQ. Expression and chromatin structures of cellulolytic enzyme gene regulated by heterochromatin protein 1. Biotechnol Biofuels. 2016;9:206.

32. Portnoy T, Margeot A, Linke R, Atanasova L, Fekete E, Sándor E, Hartl L, Karaffa L, Druzhinina IS, Seiboth B, Le Crom S, Kubicek CP. The CRE1 carbon catabolite repressor of the fungus Trichoderma reesei: a master regulator of carbon assimilation. BMC Genomics. 2011;12:269.

33. Zhao S, Yan YS, He QP, Yang L, Yin X, Li CX, Mao LC, Liao LS, Huang JQ, Xie SB, Nong QD, Zhang Z, Jing L, Xiong YR, Duan CJ, Liu JL, Feng JX. Comparative genomic, transcriptomic and secretomic profiling of Penicillium oxalicum HP7-1 and its cellulase and xylanase hyper-producing mutant EU2106, and identification of two novel regulatory genes of cellulase and xylanase gene expression. Biotechnol Biofuels. 2016;9:203. 
34. Miller GL. Use of dinitrosalicylic acid reagent for determination of reducing sugar. Anal Chem. 1959;31:426-8.

35. Lichius A, Bidard F, Buchholz F, Crom SL, Martin J, Schackwitz W, Austerlitz T, Grigoriev IV, Baker SE, Margeot A, Seiboth B, Kubicek CP. Genome sequencing of the Trichoderma reesei QM9136 mutant identifies a truncation of the transcriptional regulator XYR1 as the cause for its cellulase-negative phenotype. BMC Genomics. 2015;16(1):326.

36. Kumar S, Stecher G, Tamura K. MEGA7: molecular evolutionary genetics analysis version 7.0 for bigger datasets. Mol Biol Evol. 2016;33:1870-4.

Ready to submit your research? Choose BMC and benefit from:

- fast, convenient online submission

- thorough peer review by experienced researchers in your field

- rapid publication on acceptance

- support for research data, including large and complex data types

- gold Open Access which fosters wider collaboration and increased citations

- maximum visibility for your research: over 100M website views per year

At $\mathrm{BMC}$, research is always in progress.

Learn more biomedcentral.com/submissions 